\title{
Do Auditing and Reporting Standards Affect Firms' Ethical Behaviours? The Moderating Role of National Culture
}

\author{
Yasemin Zengin Karaibrahimoglu • \\ Burcu Guneri Cangarli
}

Received: 16 April 2014/Accepted: 5 February 2015/Published online: 22 February 2015

(c) The Author(s) 2015. This article is published with open access at Springerlink.com

\begin{abstract}
This paper aims to examine the impact of national cultural values on the relation between auditing and reporting standards and ethical behaviours of firms. Based on a regression analysis using data regarding 54 countries between the years 2007 and 2012, we found that the impact of the perceived strength of auditing and reporting standards on the perceived ethical behaviours of firms is accentuated when a society is characterized by low power distance and ingroup collectivism, and high institutional collectivism, future orientation and uncertainty avoidance. Empirically, the study addresses a gap in the literature by highlighting the influence of national culture on the effectiveness of legal settings and regulations on ethical behaviours.
\end{abstract}

Keywords Ethical behaviour - Strength of auditing and reporting standards $\cdot$ Culture $\cdot$ GLOBE

\section{Introduction}

The corporate scandals emerging during the last two decades have increased the amount of attention given to the ethical behaviours of firms (EBF). All around the world, civic organizations, as well as public and private institutions are facing the challenge of how to improve EBF. For this purpose, in recent years, forums and panels have been

\footnotetext{
Y. Zengin Karaibrahimoglu $(\bowtie)$

Faculty of Economics and Business, Accounting, University of Groningen, Nettelbosje 2, 9747 AE Groningen, The Netherlands e-mail: y.karaibrahimoglu@ rug.nl

B. Guneri Cangarli

Faculty of Business, Izmir University of Economics, Sakarya

Cad. No: 156 Balcova, Izmir 35330, Turkey

e-mail: burcu.guneri@ieu.edu.tr
}

organized in many different jurisdictions (e.g., Global Ethics Forum, European Business Ethics Forum) and ethical codes of conducts have been developed by different professions and corporations (e.g., IFAC for professional accountants, APA for psychologists; and Code of Conduct or Ethics for companies such as Amazon, Apple, and Coca Cola). New regulations have also been set (e.g., the use of corporate governance principles for corporations, the introduction of international auditing and reporting standards). The ultimate aim of these efforts is to enhance EBF through the clarification of ethical values and increasing public interest in ethics, which is considered to be an important driver of the economy (Garrison et al. 2008).

We follow Sims (1992, p. 506) and define ethical behaviour as behaviour "which is morally accepted as 'good' and 'right' as opposed to 'bad' or 'wrong' in a particular setting". Previous research shows that in addition to company-specific (micro) factors, such as personal and organizational values, EBF are also strongly affected by country-specific (macro) factors, including social, cultural, legal, political and institutional environments (Bartels 1967; Ekici and Onsel 2013; Vitell et al. 1993).

As a legal and institutional determinant, corporate governance is seen as a vital mechanism for the prevention of unethical corporate behaviours (Carcello 2009; Felo 2011). Corporate governance is a broad concept that surrounds all internal (company-specific) and external (country-specific) mechanisms with a role in monitoring management to protect all stakeholders' rights (GarcíaOsma 2006). From this point of view, all capital market regulations-including political, legal and institutional settings - that aim to enhance the quality of auditing and financial reporting are closely associated with strong corporate governance (Karaibrahimoglu 2010). Stronger auditing and reporting standards are assumed to provide more 
reliable information (Boolaky and O'Leary 2012), and consequently improve EBF. However, ethics can be affected by many contextual factors, and improving the quality of legal and institutional settings alone may not be sufficient to enhance EBF.

In fact, ethical values, attitudes and behaviours evolve under the influence of culture (Hunt and Vitell 1992; Scholtens and Dam 2007). Culture, defined as "the collective programming of the mind" (Hofstede 2001, p. 9), affects various steps-from awareness to behaviour-in ethical conduct (e.g., Alas 2006; Dubinsky et al. 1991). Accordingly, in the business ethics literature, cultural differences are perceived as the main indicators explaining variation in practices in economic or entrepreneurial activities (Alderson and Kakabadse 1994; Becker and Fritzsche 1987; Bodley 2005; Hawkins 1993; Kaptein 2004; Karnes et al. 1989; Langlois and Schlegelmilch 1990; Mensah 2013; Schultz et al. 1993). Although there are a small number of universally accepted ethical values, such as honesty or loyalty, their practical interpretations in business can vary across cultures (Smith and Hume 2005; Vitell et al. 1993). Therefore, it can be argued that the practical implementation of international auditing and reporting standards, and hence their impact on EBF can be affected by the cultural context. Although the recent literature on standards stresses the importance of cultural factors (Doupnik and Richter 2004; Tsakumis 2007), it has not yet been identified how culture influences the relationship between the strength of auditing and reporting standards (SARS) and the EBF. Based on this gap, we aim to examine the moderating impact of the cultural values on this relationship. In this paper, data on the SARS and the EBF across countries are obtained from the World Executive Opinion Survey. Hence, both variables reflect the perceptions of executives regarding the auditing and reporting standards and ethical practices in their countries. Therefore, throughout the paper, we use SARS to refer to the perceived strength of auditing and reporting standards, and EBF to perceived ethical behaviours of firms in a country.

Although there is a wide literature on auditing and reporting standards, the vast majority of studies focus on the consequences of the application of standards on the quality of financial reporting and the stock market (e.g., Daske et al. 2008; Liu et al. 2011). In contrast, only a limited number of studies focus on the association of the new standards with other issues such as EBF. To the best of our knowledge, Ekici and Onsel (2013) is the only recent study focusing on the ways in which EBF are influenced by political and legal institutions, including the SARS. However, this study did not identify the moderating impact of national culture in the legal regulations and the ethical behaviour relationship. Therefore, the current study aims to contribute to the literature by examining how this relationship changes across cultures. Identifying the impact of culture in this relationship will lead to a better understanding of the required adjustment on enforcement mechanisms, allowing for customization in accordance with cultural environment. Thus, policy makers may encourage managers, who are responsible to present faithful and reliable information to the public, to behave more ethical.

\section{Theoretical Background and Hypothesis Development}

\section{SARSs and EBFs}

Corporate governance is a management mechanism that aims at the efficient use of organizations' assets in the interests of all stakeholders, and mitigating of any opportunistic behaviour of the management (Gillan 2006). La Porta et al. (2000, p. 4) define it as "a set of mechanisms through which outside investors protect themselves against expropriation by the insiders". Good corporate governance improves ethical behaviours (Ienciu 2012). According to Hoffman and Rowe (2007), poor (weak) oversight of management by the board of directors is a major cause of corporate scandals. This clearly indicates that poor corporate governance leads management to make inappropriate or unethical decisions. Thus, strong corporate governance that leads management to assure equality, transparency, accountability and responsibility would be likely to improve EBF.

Reliable financial reporting, an essential mechanism for improving corporate governance, reduces information asymmetry and mitigates any possible agency problems among stakeholders. Therefore, it is considered as one of the major responsibilities of organizations, and it is an important part of ethical business behaviour (Webley 1999). Both in theory and practice, it is presumed that strengthening auditing and reporting standards enhance the EBF (e.g., Ekici and Onsel 2013).

Auditing and reporting standards define the principles to be applied in financial reporting and assures the fair and reliable presentation of information in financial reports. A worldwide movement to enhance the quality of auditing and reporting standards has existed since 2005. In line with the new regulations, international standards have been introduced for both auditing - International Standards on Auditing (ISAs) and also reporting-International Financial Reporting Standards (IFRSs). New standards require organizations to make reliable and faithful presentations, which are understandable, timely, verifiable, comparable and relevant to all stakeholders (IFRS Framework, pp. A33-A36), and also to assure the accuracy of the information presented in order to enhance the degree of confidence (ISA 200, p. 73). 
The new standards enhance the quality of financial reporting. However, there are some aspects of the implementation of the standards, which have been widely criticized. First of all, the new standards for financial reporting are principle-based, which provides management with greater flexibility, and which leads to the need for judgment and estimates in the preparation of financial reports. For example, for the liabilities of uncertain timing or amount, which are called as provisions, standards require a measurement at the best estimate of the expenditure to settle the present obligation at the reporting date, taking into account the risks and uncertainties related with operations (IAS-37). It is clear that the term "best estimate" is ambiguous and subject to the judgment of the management. Another example is related with the subsequent measurement of the property, plant and equipment. IAS-16 allows management to make a choice between the cost model and the revaluation model. This standard also allows management to use different depreciation models (e.g., straight line, double-declining), and to make estimates about the residual value and useful life of property, plant and equipment. Both of the examples given in the standards make a significant difference in the total assets, and consequently, the size of a firm.

The second issue is the interpretation of the standards due to its legal origin. The standards are from a common law legal origin, which may cause difficulties for entities operating in different business cultures, particularly for the code law countries, in which all rules are clearly defined and documented under the law.

The final issue is language boundaries. Language creates a challenge, even where all standards are fully translated into the local languages, because the meanings of terms may vary according to the context. Some languages lack the vocabulary resources to express the exact meaning of certain terms, making accurate translation difficult, and therefore causing potential misunderstandings. Moreover, there is subjectivity involved in the use of certain items in the standard, the exact meaning of which may be open to interpretation. An example is the different terms used to define the probabilities of some items in the estimates and judgments. These include terms such as most probable, probably, and remote. In IAS-37, it is declared that "disclosure is not required if payment is remote". Another example from IAS-18 is the statement that "it is probable that any future economic benefit associated with the item of revenue will flow to the entity". In these examples, the terms "probable" and "remote" may refer to a likelihood of anywhere between 5 and $30 \%$, depending on country and culture, and this discrepancy affects the recognition of revenue during a period, and, in turn, the total turnover, and consequently, the financial performance of firms. In their study, Doupnik and Richter (2003) find that there exists a language-culture and translation effect in the interpretations of international accounting standards and suggest that non-native English speakers may be less confident in their interpretation of uncertainty terms expressed in English than in their native language. Furthermore, it is argued by Doupnik and Richter (2004) that the culture affects the interpretations of verbal probability terms used in international accounting standards in a systematic and predictable manner. In another study, Doupnik and Riccio (2006), argued that national cultural values may affect the interpretation of probability expressions used in IFRSs, and consequently that may lead differences in the practices.

Although standards have grey areas, they are based on a conceptual framework that aims to direct management to be flexible in making judgments, estimates, and choices in order to reflect the economic reality of each corporation. Also, it is argued that this flexibility allows firms to use tailor-made reporting standards, suited to the needs of entities, which facilitates the quality of the financial reporting. Thus, it is expected that management would use the flexibility allowed by the standards to make decisions that consider the interests of all relevant stakeholders-i.e., ethical behaviours, rather than only the interests of majority shareholders, i.e., unethical behaviours. Consequently, organizations are pressured to behave more ethical by this flexibility, and the qualitative characteristics (reliable, faithful, understandable, timely, verifiable, comparable and relevant) demanded for financial reporting. Also, the new standards both for auditing and reporting assign all responsibility for the presentation of misleading information to the management, thus encouraging it to become more ethical in its organizational decisions. Considering the above benefits, it is expected that a stronger auditing and reporting standards set will improve EBF.

\section{Moderating Role of Culture in SARS-EBF Relationship}

One of the main issues is whether or not the adoption of international auditing and reporting standards results in uniformly strong governance (Boolaky and O'Leary 2011). Variation in the application of accounting standards can be expected as consequence of differences in local business environment and in the institutional structure of a country (Chen et al. 2010). Furthermore, even high quality reporting standards may not necessarily improve the quality of accounting information presented (Ball et al. 2003), as the quality of financial reporting also depends on the incentives of both the managers and auditors (Ball et al. 2003), their interpretation, enforcement mechanisms and litigation (Barth et al. 2008), local economic systems, and culture (Chen et al. 2010; Qu et al. 2012; Rezaee et al. 2010). 
According to previous empirical studies, while some researchers argue that the quality of financial reporting has been enhanced by the introduction of IFRSs (for an extensive review: Barth et al. 2008 in 21 European countries; Daske et al. 2008 in 26 countries all over the world; Liu et al. 2011 in China), a number of others find decreasing accounting quality (for an extensive review: Paananen 2008, a study that examines Sweden; Paananen and Lin 2009, a study conducted in Germany; Jeanjean and Stolowy 2008, a study comparing companies in Australia, France, and the UK).

In many jurisdictions, the main opposition to international auditing and reporting standards concerned the influence of culture on their application by practitioners and auditors (Perera 1994). Variation in cultural characteristics across countries results in different degrees of harmonization between local standards and the newly introduced ones (Ding et al. 2005). Therefore, the impact of SARS on EBF may differ across cultures.

In order to examine the moderating role of culture on the relationship of SARS with EBF, we utilized the framework provided by global leadership and organizational behaviour effectiveness study (GLOBE), which assesses the cultural characteristics of 62 societies based on the data from 951 organizations and 17,000 managers (House et al. 2004). It is widely known that, among the many cultural frameworks designed to analyse national cultures (e.g., Hall 1959; Hofstede 2001; Schwartz 1992; Trompenaars 1994), GLOBE is considered as the most ambitious effort (Steers et al. 2013). Compared to Hofstede's study (2001), GLOBE is considered to be both more recent and comprehensive (Shi and Wang 2011). Moreover, its methodology is found to have greater validity and reliability (Parboteeah et al. 2005).

National cultures are assessed on nine dimensions in the GLOBE study, namely; power distance (PDI), future orientation (FUTR_O), human orientation, performance orientation, in-group collectivism (IGC), institutional collectivism (INST_C), assertiveness, uncertainty avoidance (UAI) and gender egalitarianism. The current study aims to explore the moderating role of all the dimensions, with the exception of gender egalitarianism, as neither a literature review nor theoretical reasoning suggested any relevance for this dimension to SARSEBF relationship.

PDI refers to the degree to which less powerful members of a society accept the unequal distribution of power. In high PDI cultures, powerful individuals are privileged, and their violation of rules may be ignored by other members in the society (House et al. 2004). From the ethical behaviour perspective, it is known that in low PDI cultures, people are more sensitive to ethical issues due to a strong belief in the protection of the rights of all people (Chan and Cheung
2012). Thus, in low PDI cultures, even in grey areas in the legal system, efforts are made to achieve the best outcomes for all parties. On the other hand, in high PDI cultures, inequality in distribution of resources can be characterized by a relatively low regard for ethics (Scholtens and Dam 2007). Accordingly, in such societies, grey areas in the legal system are more likely to be interpreted in favour of powerful parties such as majority shareholders (Blodgett et al. 2001). Therefore, we expect that the positive relationship between SARS and EBF will be negatively influenced by PDI. Specifically, in high PDI cultures, the impact of SARS on EBF is weaker than in low PDI cultures.

Hypothesis 1 PDI weakens the relationship between SARS and EBF in a country.

FUTR_O concerns the way people perceive and treat time. High FUTR_O leads people to focus on the long-term in future related activities, such as planning and investing. In future oriented societies, people tend to be more flexible and adaptive, and saving for the future is emphasized (House et al. 2004). On the other hand, in societies where FUTR_O is low, people focus more on immediate results, and organizations tend to be bureaucratic and inflexible (House et al. 2004; Steers et al. 2013). Alas (2006) described societies with high FUTR_O as those in which the requirements for well-established standards of ethical behaviour are weaker. Moreover, the FUTR_O dimension has many commonalities with Hofstede's long-term orientation (Steers et al. 2013), which is cited as being positively associated with ethical behaviour (Tsui 1996). Therefore, it can be claimed that in future oriented societies, individuals try to choose the option which is more sustainable, rather than the one producing short-term results which benefits only few parties. Therefore, people in future oriented societies are willing to interpret the legal base, including auditing and reporting standards, in favour of sustainable outcomes, and hence the impact of SARS will be stronger on EBF in such societies.

Hypothesis 2 FUTR_O strengthens the relationship between SARS and EBF in a country.

Human orientation is defined as the degree to which people reward fairness, altruism and generosity (House et al. 2004). In societies, which are characterized by high human orientation, people give importance to the interests of others. In contrasts, in low human oriented societies, individuals focus more on their own self-interests, and value pleasure, comfort and self-enjoyment. A small number of studies have examined the relationship between human orientation and ethical behaviour. Parboteeah et al. (2005) found that human orientation is negatively associated with a willingness to justify ethically suspect 
behaviours, probably due to the nurturing and cooperative nature of this type of society. Moreover, Alas (2006) includes human orientation as one of the characteristics of societies which have low needs for well-established standards for ethics. Those societies emphasize concern for the well-being of others, thus leading to the interpretation of the rules or standards in line with ethical behaviour. Therefore, we argue that the positive relationship between SARS and EBF is stronger in human oriented societies.

Hypothesis 3 Human orientation strengthens the relationship between SARS and EBF in a country.

Performance orientation is the degree to which high performance is encouraged and rewarded (House et al. 2004). High performance orientation characterizes an environment in which individuals believe that they can control their own destiny, and value assertiveness and success. By definition, performance orientation overlaps with the masculinity dimension defined in Hofstede's study (2001), in terms of the value given to success and materialism. As the literature on the relationship between performance orientation and ethical behaviour is limited, we utilized studies examining the association between masculinity and ethical behaviour. Blodgett et al. (2001) argue that people in masculine societies feel great pressure to succeed in their careers, and are less concerned about others. In line with this argument, Vitell et al. (1993) show that many business practices considered valid in masculine cultures can be perceived as unethical in feminine cultures. As a result, the quality of corporate governance practices significantly decreases in masculine cultures (Chan and Cheung 2012). On the other hand, cultures that are less oriented to performance are more consensus-oriented, and general well-being is given more importance (House et al. 2004). Accordingly, we argue that in high performance oriented societies, managers are more likely to interpret the grey areas in auditing and reporting standards in such a way as to present a higher level of performance, based on the flexibility allowed. Therefore, the likelihood of those standards leading to more ethical decision-making will decline in high performance oriented societies.

Hypothesis 4 Performance orientation weakens the relationship between SARS and EBF in a country.

Individuals' relations to social organizations and perceptions of self-identity have been used in many studies to differentiate between cultures (e.g., Chan and Cheung 2012; Smith and Hume 2005; Steers et al. 2013; Vitell et al. 1993; Zhang et al. 2013). While Hofstede (2001) conceives of the relationship as having a single dimension, i.e., collectivism-individualism, the GLOBE project recognizes two independent dimensions: IGC and INST_C (Chhokar et al. 2012). IGC refers to the degree to which individuals express pride, loyalty and cohesiveness in their immediate groups, such as family, circle of close friends or work team (House et al. 2004). The in-group protects the interests of the individual, but expects unquestioning loyalty in return. Therefore, when IGC is high, people perceive themselves as dependent on the groups they belong to, instead of making independent judgments. INST_C, on the other hand, represents a very different type of collectivism. Gelfand et al. (2004, p. 476) describe societies with high level of INST_C as "...future focused and performance oriented, yet they seek to accomplish such orientations through practices that emphasize being concerned about others, and not being assertive or power domineering." As the comparisons of definitions yield that these two represent totally different dimensions, not surprisingly, many countries in GLOBE sample have significantly different scores on IGC and INST_C (Chhokar et al. 2012). Therefore, we treat these dimensions as completely separate in the construction of the argument about their moderating impact on SARS-EBF relationship.

By definition, IGC has more commonalities with Hofstede's individualism/collectivism dimension compared to INST_C. Therefore, we utilized the rich literature on the relationship between individualism/collectivism and ethical behaviour while exploring IGC's potential moderation impact. Individualism/collectivism has been used in many studies to explain the impact of national culture on ethical behaviours (e.g., Chan and Cheung 2012; Smith and Hume 2005; Vitell et al. 1993; Zhang et al. 2013). For instance, ethical sensitivity of US managers is found to be higher than that of their Turkish counterparts' due to the effect of individualism (Simga-Mugan et al. 2005). Similar results are also found in a study which compares the ethical sensitivity of government personnel in US and Hong Kong. Accordingly, compared to government personnel in US, those in Hong Kong have a greater tendency to perceive ethical behaviours as existing purely within the limits of written rules (Dolecheck and Dolecheck 1987). A further indication of this tendency is the lower crime levels found in Scandinavian countries, due to lower PDI and higher individualism, factors which outweigh the strength of the legal system (Coffee 2001). This result is interpreted as revealing that in individualistic cultures, people are expected to show respect for the rights of the individuals, rather than protecting the interests of their in-group at the expense of outgroups (Franke and Nadler 2008). Therefore, at the stages of ethical decisions, they are less likely to be influenced by groups or group leaders (Vitell et al. 1993). Based on these arguments, we claim that those in individualistic societies are more prone to interpret the legal system in an unbiased way when making ethical decisions. Hence, there is an increased likelihood of making decisions which are more ethical because of the importance of the individual's own 
judgments relative to the need to protect the interests of their in-groups when interpreting the auditing and reporting standards. Correspondingly, we expect that IGC has weakening impact in SARS-EBF relationship.

In contrast to IGC, INST_C has been characterized as having a future focus, and being opposed to assertiveness or power-domineering (Gelfand et al. 2004). From the firms' perspective, INST_C leads to decisions which are the most beneficial for the long-term sustainability of the whole institution, including all the relevant parties. Therefore, we can argue that managers are more willing to use the auditing and reporting standards to make sustainable decisions in institutionally collectivist societies as they are motivated to maximize the benefit to their organizations. For this reason, we hypothesize that INST_C and IGC have opposite impacts on SARS-EBF relationship.

Hypothesis 5a IGC weakens the relationship between SARS and EBF in a country.

Hypothesis 5b INST_C strengthens the relationship between SARS and EBF in a country.

Assertiveness is the degree to which people are assertive, confrontational and aggressive in their relationships. In societies characterized by high levels of assertiveness, the stronger members are admired, competition is valued, and people are direct and aggressive in their relationships (House et al. 2004). In some aspects, assertiveness has commonalities with performance orientation. However, performance orientation concerns results, while assertiveness mainly concerns social relationships (Parboteeah et al. 2005). In assertive societies, people tend to think of others as being opportunistic, and are concerned to protect their own interest (House et al. 2004). They are, therefore, more likely to try to justify ethically suspect behaviours (Parboteeah et al. 2005). Also, the tendency to be cooperative and to consider the well being of others is relatively weak in those societies. Therefore, in highly assertive societies, individuals are more prone to interpret the legal regulations, such as auditing and reporting standards, in favour of themselves or the more powerful members of society, and show less interest in protecting the weaker members. Accordingly, we claim that the positive relationship between SARS and EBF is negatively influenced by the level of assertiveness.

Hypothesis 6 Assertiveness weakens the relationship between SARS and EBF in a country.

UAI expresses the degree to which the members of a society feel uncomfortable with uncertainty and ambiguity (Hofstede 2001). In high UAI societies, people are more emotional and intolerant, and less accepting of personal- risk. Moreover, they have a significantly greater need to be guided by rules, principals and traditions, due to greater levels of uncertainty about the future and the appropriate conduct (House et al. 2004). They expect conduct to be guided by well-defined regulations, and therefore they have a lower degree of ethical sensitivity than in low UAI societies (Weaver 2001). Accordingly, their ethical judgment abilities have not been well developed (Vitell et al. 1993). Thus, where issues are not clearly identified by written rules, they may feel lost and anxious, and tend to make less appropriate decisions. In line with this claim, Chan and Cheung (2012) identify a lower quality of corporate governance practices in high UAI cultures. Due to the dynamic nature of business practices, there is a need for frequent reappraisal and reconsideration of appropriate conduct, especially for the issues regulated by principles that allow for flexibility. We argue that this need for flexibility and adaptation means that, compared to low UAI societies, high UAI societies perform less effectively in the grey areas of the auditing and reporting standards. Accordingly, we hypothesize that UAI weakens the positive relationship between SARS and EBF.

Hypothesis 7 UAI weakens the relationship between SARS and EBF in a country.

\section{Methodology}

Data and Measures

The data cover 62 societies between the years 2007 and 2012. The initial sample was 372 society-year observations, including all countries used in the GLOBE study (House et al. 2004). From this initial sample, Germany and South Africa (a total of 24 society-year observations) were excluded due to data segmentation, as the former was divided into west and east, and the latter into a Caucasian and Indigenous sample. Switzerland (a total of 12 society-year observations), which has German and French Speaking samples, was excluded due to the dual classification in cultural clusters. The Czech Republic and Iran (a total of 12 society-year observations) were excluded due to the missing cultural values. The final sample comprises of 324 society-year observations for 54 countries.

Data for EBF and SARS were gathered from the World Competitiveness Index (WCI) database, through the World Economic Forum's Executive Opinion Survey. The Executive Opinion Survey, a worldwide ranking extending more than 30 years, was chosen for providing both a qualitative and quantitative portrait of countries' economic and business environment. The survey is 
carried out with the help of more than 160 partner institutes (research institutes, universities, business organizations, etc.) worldwide by using face-to-face interviews with business executives, telephone interviews and mailings and an online survey. In order to capture a strong and representative sample, the partner institutes are tasked to prepare a "sample frame," or large list of potential respondents. Based on the list, each year, a random selection of firms, which receive the survey, is applied in order to reduce the survey bias. According to 2012 sources, a total of 15,000 surveys were sent out to 142 economies. After data processing, 14,059 (93\%) were used to create a unique resource, covering all social and economic indicators, most of which would not otherwise be publicly available, from multiple countries worldwide (WCI 2012).

In the Executive Opinion Survey, our dependent variable, EBF was measured with one item question: "How would you compare the corporate ethics (ethical behaviour in interactions with public officials, politicians, and other enterprises) of firms in your country with those of other countries in the world?". Participants were asked to indicate their response to this question on a seven-point Likert scale $(1=$ among the worst in the world; $7=$ among the best in the world). Although the survey measured EBF with a single item, it has been found reliable in previous research (Ekici and Onsel 2013; Mehanna and Yazbeck 2009).

Similarly, SARS was measured with a single question: "In your country, how would you assess financial auditing and reporting standards regarding company financial performance?" Participants reflected their opinions on a seven-point Likert scale $(1=$ among the worst in the world; 7 = among the best in the world).

Our study may be subject to a common method bias due to collecting the dependent and independent variables from the same survey and from the same respondents. Podsakoff et al. (2012) suggest several ways to overcome this problem. Therefore, to avoid a possible common method bias, in our analysis we decided to use the data for our independent variable collected at a different time period. Specifically, the perceived SARS was measured based on the last year's score. Using this measure is fair when we consider a time lag between the auditing and reporting standards perception and its reflection to the perceived EBF. While the survey questions regarding SARS remain the same, considering the random sampling process, the survey is sent out to different participants. As such, this may help to deal with common source biases that possibly may result from using dependent and independent variables coming from the same source. In that term, as informed by Podsakoff et al. (2012), using SARS score of the previous year reduces a possible common method bias. In order to assure the robustness of the findings, in our sensitivity analyses we also used an alternative secondary source data that proxy the SARS.

Previous research which examines the reasons of unethical behaviour mostly ignores the role of competition (Shleifer 2004). However, considering the growth and income enhancing effect of competition, it may improve EBF in the long run (Shleifer 2004), since the intention to behave ethically increases as societies get richer (Friedman 2006). Thus, following Shleifer (2004) and Friedman (2006), in the current study, competition, which referred to the level of market competition in the country, was used as a control variable. The data for market competition were gathered from the WCI database. It was computed based on the weighted average of 14 items, measured on a seven-point Likert scale $(1=$ lowest and $7=$ highest $)$. Sample items include the extent of market dominance, effectiveness of anti-monopoly policy and prevalence of trade barriers.

Countries' legal system influences the business environment where firms operate. In general, commercial laws are driven from two broad traditions; common law and civil law (La Porta et al. 1998). According to La Porta et al. (1998), legal systems are determinants of corporate governance, and common law countries give stronger legal rights and investor protection to market participants. Consequently, it is expected that firms operating in common law countries are more tend to behave ethically. Therefore, following La Porta et al. (1998), the legal system of the countries was used as a control variable. Common law was a dummy variable equal to one if the origin of country's legal system was derived from common law, and zero if from a civil law country. The data for the legal origin of countries were gathered from the data set used in La Porta et al. (1998) and downloaded from Shleifer's website.

Additionally, as an economic control variable that affects the level of development, GDP per capita is considered. GDP per capita is an indicator of standards of living in a country and it shows the relative performance of countries. Friedman (2006) and Shleifer (2004) argues that there is a positive relationship between EBFs and GDP per capita. Therefore, GDP effect must be controlled in a crosscountry study. The data for GDP per capita were collected from the World Bank database (2012).

The moderating variable, national culture was measured based on the country scores regarding the eight cultural dimensions (PDI, FUTR_O, human orientation, performance orientation, IGC, INST_C, assertiveness and UAI) defined in the GLOBE project (House et al. 2004). ${ }^{1}$ In this

\footnotetext{
1 The data was gathered from the online resources available on Professor Anne-WilHarzing's web page from University of Melbourne, Australia available on http://www.harzing.com/resources. htm.
} 
well-known project, data were collected from 17,000 managers from 951 different organizations, who assessed the cultural characteristics of 62 societies on a seven-point Likert scale.

In the GLOBE study, each country was measured along each of the dimensions. In order to provide more robust findings, we considered the possible impact of the multivariate context of cultural dimensions in each country and used cultural clusters defined in the GLOBE study as control dummies. In the sensitivity analysis, the predicting and moderating roles of the cultural clusters were examined as an alternative to our main analysis. The list of the cultural clusters with associated societies and the cultural characteristics are presented in "Appendix 1" section.

\section{Analysis}

This study uses a regression analysis methodology to examine the moderating role of culture on EBF and SARS relation. Ethical behaviour is closely associated with many different social and economic issues in the market, therefore, in order to control country specific factors, the level of market competition, the legal origin of countries, GDP per capita and cultural clusters were added into the model as control variables. We employed pooled OLS estimation with robust standard errors for the estimation of the coefficients.

\section{Results}

Table 1 presents the correlation results among EBF, SARS, GLOBE's cultural dimensions, countries' legal origin, and market competition. There were significant correlations between the EBF and the control variables. The use of those variables to control country-specific differences has an explanatory power for the analysis.

Table 2 shows the results of the multiple regression analysis, SARS and cultural dimensions as predictors of EBF. As the cultural dimensions are correlated with each other, the impact of each cultural dimension was examined in separate models and control dummies for 10 cultural clusters were used. All models for the eight different cultural dimensions are significant at 0.01 . In all models, in line with the theory, SARS has a significant positive impact on EBF.

Table 3 shows the results of the multiple regression analysis for the moderating effect of culture on the association of SARS and EBF. Similarly, the impact of each cultural dimension was examined in separate models and control dummies for 10 cultural clusters were used. According to the regression results documented in Model 1, the interaction term of SARS and PDI becomes negative and significant, indicating that higher PDI weakens the impact of SARS on EBF, as hypothesized in this study. On the other hand, as expected, the regression results in Model 2 show that the interaction term of SARS and FUTR_O is positive and significant, suggesting that higher FUTR_O strengthens the impact of SARS on EBF. Model 5 documents that increased IGC weakens the impact of SARS on EBF. In Model 6, the interaction term of SARS and INST_C becomes positive and significant, indicating that higher INST_C strengthens the impact of SARS on EBF. Finally, contrary to our expectations, Model 8 shows that the interaction term of SARS and UAI is positive and significant, supporting the idea that higher UAI strengthens the impact of SARS on EBF. The results provide no significant moderating impact of human orientation, performance orientation or assertiveness on SARS and EBF relation.

The significant moderating effects of each cultural dimension on SARS-EBF relationship are also presented separately in Fig. 1.

\section{Sensitivity Analysis}

In order to check the robustness of the results we conducted several sensitivity analyses by using alternative measures or estimation methods.

First, to test the sensitivity of the results to the measure we used for SARS, we run the regressions by using a secondary data source. An IFRS dummy that assumed to proxy the SARS was used. For countries where IFRS is required for financial reporting it takes the value of 1,0 otherwise. Tables 4 and 5 report the results of the multiple regression analysis using IFRS and reveal similar results with respect to the main findings reported in Tables 2 and 3. In addition to our findings, if IFRS is used, the cultural dimensions that are insignificant in the main findings are found significant. According to the results, the effectiveness of IFRS on EBF strengthens in countries with high INST_C, FUTR_O, UAI, human orientation and performance orientation while it weakens in countries with high PDI, IGC and assertiveness. The results are in line with our expectations except for the performance orientation and UAI. Even though the use of IFRS is a good proxy for financial reporting quality, it does not capture the auditing standards. Therefore, the sensitivity of the results might be due to the differences in the scope of IFRS and SARS.

Second, in order to test the sensitivity of our analysis to the model specification that takes only one of the cultural dimensions into account at a time, we used cultural clusters as predictors and moderators in two different analyses. Based on the similarities and differences in cultural characteristics, the GLOBE study divides the countries into cultural (regional) clusters. Considering the multivariate context of culture, using cultural clusters might be more explanatory than a single cultural dimension at a time on. 


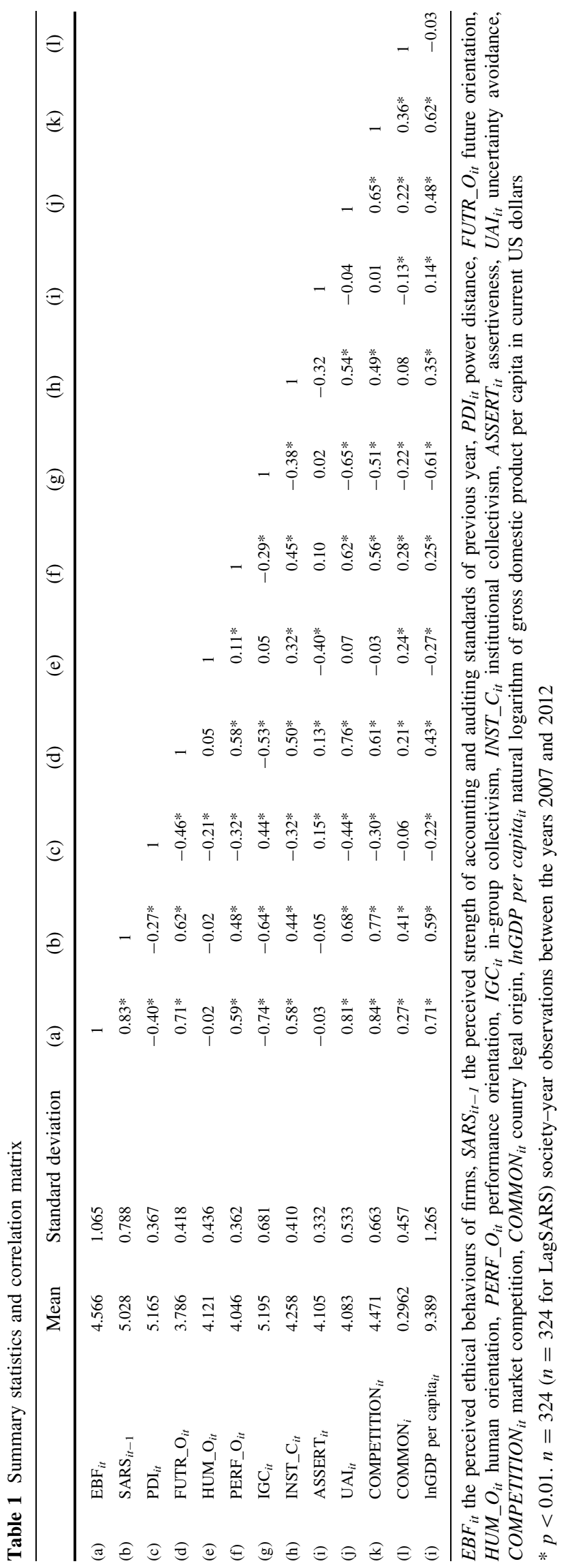

The results, presented in Tables 6 and 7, indicate that the moderating impact of clusters is significant and weakening for three clusters, namely; Middle East, Latin America and Eastern Europe. The Middle East cluster, where Turkey, Kuwait, Egypt, Morocco and Qatar take place, is characterized by high score on IGC, medium score on assertiveness, humane orientation, INST_C, performance orientation, PDI, and low score on FUTR_O, gender egalitarianism and UAI. Latin America is the largest cluster including Ecuador, El Salvador, Columbia, Bolivia, Brazil, Guatemala, Argentina, Costa Rica, Venezuela and Mexico. It is known with high IGC, medium assertiveness, human orientation, gender egalitarianism, and PDI, low FUTR_O, INST_C, performance orientation and UAI. Finally, Eastern Europe cluster consist of Albania, Georgia, Greece, Hungary, Kazakhstan, Poland, Russia and Slovenia. Its main cultural characteristics are high scores on assertiveness, gender egalitarianism, IGC, medium scores on INST_C, humane orientation and PDI, and low scores on FUTR_O, performance orientation and UAI. When the common characteristics of the three clusters are examined, it is seen that they scored high on IGC, medium on humane orientation and PDI, and low in FUTR_O and UAI. Therefore, it can be said that overall, the results are in line with our findings obtained with cultural values.

Third, to test the sensitivity of the results to the choice of the cultural values, we run all regressions by using Hofstede's cultural values. It is known that GLOBE study takes Hofstede's study $(1980,2001)$ as a base. Therefore, between two studies there are many similarities in terms of cultural values that are used to assess differences and similarities in mindsets across countries. In Hofstede's study $(1980,2001)$ societies are assessed based on five cultural dimensions, namely; PDI, IGC, time orientation (short term vs. long term), UAI and masculinity versus femininity. All these dimensions were used in our sensitivity check. Table 8, Panels A and B document that the impact of SARS on EBF weakens if society is characterized by high UAI, high PDI, high masculinity and low individualism. In general, the results are similar to the findings presented in Tables 2 and 3 for all dimensions except for UAI. In this area, the findings obtained from Hofstede's framework show weakening impact on SARSEBF relation. The difference in our findings is most probably due to utilizations of different measurements in GLOBE and Hofstede's study. As indicated by Venaik and Brewer (2008), although both studies use the same termUAI - they utilize different questions that aim to address different practices. For instance, Hofstede (1980, 2001) focus more on the role of traditions to cope with uncertainties and separate this dimension from risk taking, while GLOBE focus more on business practices such as risk taking in business decisions (House et al. 2004). Therefore, 
Table 2 Regression results of EBF on SARS and GLOBE cultural values

\begin{tabular}{|c|c|c|c|c|c|c|c|c|}
\hline Dependent variable: $\mathrm{EBF}_{i t}$ & Model 1 & Model 2 & Model 3 & Model 4 & Model 5 & Model 6 & Model 7 & Model 8 \\
\hline Constant & 0.520 & $-2.082 * * *$ & $-2.206 * * *$ & $-3.464 * * *$ & $1.564 * * *$ & $-2.664 * * *$ & -0.375 & $-2.615^{* * *}$ \\
\hline \multicolumn{9}{|l|}{ Test variables } \\
\hline $\mathrm{SARS}_{i t-1}$ & $0.349 * * *$ & $0.325 * * *$ & $0.364 * * *$ & $0.307 * * *$ & $0.252 * * *$ & $0.355 * * *$ & $0.339 * * *$ & $0.288 * * *$ \\
\hline $\mathrm{PDI}_{i t}$ & $-0.307 * * *$ & & & & & & & \\
\hline FUTR_O ${ }_{i t}$ & & $0.316 * * *$ & & & & & & \\
\hline HUM_O $_{i t}$ & & & $0.209 * * *$ & & & & & \\
\hline PERF_O $i t$ & & & & $0.635 * * *$ & & & & \\
\hline $\mathrm{IGC}_{i t}$ & & & & & $-0.331 * * *$ & & & \\
\hline INST_C $_{i t}$ & & & & & & $0.391 * * *$ & & \\
\hline $\operatorname{ASSERT}_{i t}$ & & & & & & & $-0.188 * *$ & \\
\hline $\mathrm{UAI}_{i t}$ & & & & & & & & $0.505^{* * *}$ \\
\hline \multicolumn{9}{|l|}{ Control variables } \\
\hline COMPETITION $_{i t}$ & $0.656 * * *$ & $0.632 * * *$ & $0.683 * * *$ & $0.555^{* * *}$ & $0.683 * * *$ & $0.647 * * *$ & $0.694 * * *$ & $0.570 * * *$ \\
\hline $\mathrm{COMMON}_{i}$ & -0.038 & -0.027 & -0.050 & -0.024 & -0.038 & -0.002 & -0.018 & -0.026 \\
\hline $\operatorname{lnGDP}$ per capita ${ }_{i t}$ & $0.141 * * *$ & $0.139 * * *$ & $0.164 * * *$ & $0.186^{* * *}$ & $0.084 * * *$ & $0.142 * * *$ & $0.158 * * *$ & $0.141 * * *$ \\
\hline Cluster dummies & Yes & Yes & Yes & Yes & Yes & Yes & Yes & Yes \\
\hline Prob $>F$ & 0.000 & 0.000 & 0.000 & 0.000 & 0.000 & 0.000 & 0.000 & 0.000 \\
\hline$R^{2}$ & $0.900 * * *$ & $0.898 * * *$ & $0.896 * * *$ & $0.913 * * *$ & $0.905^{* * *} *$ & $0.902 * * *$ & $0.895 * * *$ & $0.914 * * *$ \\
\hline
\end{tabular}

$E B F_{i t}$ the perceived ethical behaviours of firms, $S A R S_{i t-1}$ the perceived strength of accounting and auditing standards of previous year, $P D I_{i t}$ power distance, FUTR_O $O_{i t}$ future orientation, $H U M_{-} O_{i t}$ human orientation, PERF_O $O_{i t}$ performance orientation, IGC $C_{i t}$ in-group collectivism, $I N S T_{-} C_{i t}$ institutional collectivism, ASSERT ${ }_{i t}$ assertiveness, UAI ${ }_{i t}$ uncertainty avoidance, COMPETITION ${ }_{i t}$ market competition, COMMON ${ }_{i t}$ country legal origin, $\ln G D P$ per capita ${ }_{i t}$ natural logarithm of Gross domestic product per capita in current US dollars, cluster dummies, the dummy variables to control the effect of cultural clusters defined in the GLOBE study

$*$, **, *** $p<0.10,<0.05$ and $<0.01$ (one-sided tests), respectively. $n=324$ society-year observations between the years 2007 and 2012

most country scores on UAI in Hofstede's and GLOBE studies are negatively correlated.

Furthermore, to understand the sensitivity of the results to the estimation method, the regression analysis were run by random-effect generalised least square estimation model by excluding the cultural cluster dummies. The results are similar to pooled OLS in terms of direction and significance of the coefficients.

Based on the sensitivity analyses, we conclude that our main findings also generally hold when alternative measures for independent or moderating variables were used or alternative estimation method was applied.

\section{Discussion}

This study examines the moderating role of cultural values on relationship between SARS and EBF. Results provide empirical evidence to support the argument that the positive relationship between SARS and EBF is moderated by certain cultural values, namely; PDI (hypothesis 1), FUTR_O (hypothesis 2), IGC (hypothesis 5a), INST_C (hypothesis 5b), and UAI (hypothesis 7). However, empirical data showed no significant moderation impact for human orientation (hypothesis 3), performance orientation (hypothesis 4) and assertiveness (hypothesis 6).

The business ethics literature contains a myriad of studies describing the relationship between cultural values and EBF. However, although there are a number of studies in which culture has been treated as an independent variable, its moderating impact is generally ignored. In this study, the identification of the moderating role of cultural values in SARS-EBF relationship is considered important in increasing our understanding of the complex role of cultural values in ethical conduct.

\section{SARS-EBF Relationship}

Our findings indicate that SARS improves EBF through encouraging firms to become more faithful, accurate, understandable, timely, verifiable, comparable and relevant in sharing financial information with all other stakeholders. The strong positive impact of the SARS-EBF relationship emerges as an important outcome of recent regulations set by policy makers designed to improve financial reporting and auditing standards.

Although we showed that the stronger perception on auditing and reporting standards yield higher levels of 
Table 3 Two-way moderating regression results of EBF on SARS and GLOBE cultural values

\begin{tabular}{|c|c|c|c|c|c|c|c|c|}
\hline Dependent variable $\mathrm{EBF}_{i t}$ & Model 1 & Model 2 & Model 3 & Model 4 & Model 5 & Model 6 & Model 7 & Model 8 \\
\hline Constant & $-3.591 * *$ & 1.941 & $-4.524 * *$ & -1.561 & $-5.428 * * *$ & $9.286 * * *$ & $-6.004 * *$ & $2.691 * * *$ \\
\hline \multicolumn{9}{|l|}{ Test variables } \\
\hline SARS $_{i t-1}$ & $1.402 * * *$ & $0.634 * *$ & $0.628 * *$ & -0.057 & $1.436 * * *$ & $-1.986 * * *$ & $1.297 * *$ & $-0.917 * * *$ \\
\hline $\mathrm{PDI}_{i t}$ & 0.434 & & & & & & & \\
\hline FUTR_O ${ }_{i t}$ & & $-1.024 * *$ & & & & & & \\
\hline HUM_O ${ }_{i t}$ & & & 0.367 & & & & & \\
\hline PERF_O $i t$ & & & & -0.166 & & & & \\
\hline $\mathrm{IGC}_{i t}$ & & & & & $0.737 * *$ & & & \\
\hline INST_C $_{i t}$ & & & & & & $-2.395 * * *$ & & \\
\hline $\operatorname{ASSERT}_{i t}$ & & & & & & & 0.751 & \\
\hline $\mathrm{UAI}_{i t}$ & & & & & & & & $-0.917 * * *$ \\
\hline $\mathrm{PDI} * \mathrm{SARS}_{i t}$ & $-0.175^{* *}$ & & & & & & & \\
\hline FUTR_O $*$ SARS $_{i t-1}$ & & $0.284 * * *$ & & & & & & \\
\hline HUM_O $*$ SARS $_{i t-1}$ & & & -0.027 & & & & & \\
\hline PERF_O $*$ SARS $_{i t-1}$ & & & & 0.138 & & & & \\
\hline $\mathrm{IGC}^{*} \mathrm{SARS}_{i t-1}$ & & & & & $-0.207 * * *$ & & & \\
\hline INST_C $_{-} * \mathrm{SARS}_{i t-1}$ & & & & & & $0.568 * * *$ & & \\
\hline ASSERT $^{*}$ SARS $_{i t-1}$ & & & & & & & -0.196 & \\
\hline $\mathrm{UAI}^{*} \mathrm{SARS}_{i t-1}$ & & & & & & & & $0.299 * * *$ \\
\hline \multicolumn{9}{|l|}{ Control variables } \\
\hline COMPETITION $_{i t}$ & $0.605 * * *$ & $0.574 * * *$ & $0.656 * * *$ & $0.518 * * *$ & $0.725 * * *$ & $0.579 * * *$ & $0.679 * * *$ & $0.530 * * *$ \\
\hline $\mathrm{COMMON}_{i}$ & -0.034 & -0.024 & $-0.094^{*}$ & $-0.123^{*}$ & $-0.082 *$ & 0.050 & $-0.067 *$ & 0.016 \\
\hline $\operatorname{lnGDP}$ per capita ${ }_{i t}$ & $0.180 * * *$ & $0.176 * * *$ & $0.221 * * *$ & $-0.208 * * *$ & $0.113 * * *$ & $0.170 * * *$ & $0.212 * * *$ & $0.171 * * *$ \\
\hline Cluster dummies & Yes & Yes & Yes & Yes & Yes & Yes & Yes & Yes \\
\hline Prob $>F$ & 0.000 & 0.000 & 0.000 & 0.000 & 0.000 & 0.000 & 0.000 & 0.000 \\
\hline$R^{2}$ & $0.848 * * *$ & $0.858 * * *$ & $0.834 * * *$ & $0.851 * * *$ & $0.876^{* * *}$ & $0.881 * * *$ & $0.835 * * *$ & $0.900 * * *$ \\
\hline
\end{tabular}

$\overline{E B F_{i t} \text { the perceived ethical behaviours of firms, } S A R S_{i t-1} \text { the perceived strength of accounting and auditing standards of previous year, } P D I_{i t}}$ power distance, $F U T R \_O_{i t}$ future orientation, $H U M_{-} O_{i t}$ human orientation, PERF_O $O_{i t}$ performance orientation, IGC $C_{i t}$ in-group collectivism, $I N S T_{-} C_{i t}$ institutional collectivism, ASSERT $T_{i t}$ assertiveness, $U A I_{i t}$ uncertainty avoidance, COMPETITION $N_{i t}$ market competition, COMMON country legal origin, $\ln G D P$ per capita $_{i t}$ natural logarithm of Gross domestic product per capita in current US dollars, Cluster dummies the dummy variables to control the effect of cultural clusters defined in the GLOBE study

$*, * *, * * * p<0.10,<0.05$ and $<0.01$ (one-sided tests), respectively. $n=324$ society-year observations between the years 2007 and 2012

$\mathrm{EBF}$, this relationship is moderated by cultural values. In other words, the benefit in enhancing ethical behaviours derived from the standards varies according to cultural dimensions of each society. Our results show that societies, which scored low in PDI and IGC, and high in INST_C, FUTR_O and UAI, may benefit most from the standards. Other types of society are more likely to need enforcement mechanisms to counteract the impact of their cultural values, which would otherwise reduce the effectiveness of SARS.

\section{Weakening Moderating Impact of PDI and IGC}

In the business ethics literature, PDI and IGC are the most frequently cited in explanations of variation in ethical behaviour among societies (e.g., Blodgett et al. 2001; Chan and Cheung 2012; Scholtens and Dam 2007; Smith and Hume 2005; Steers et al. 2013; Vitell et al. 1993; Zhang et al. 2013). Previous research showed that these two dimensions have a strong negative impact on ethical behaviour. Our results are consistent with the previous research and our hypotheses, so that PDI and IGC are found to have weakening moderating impact on SARSEBF relationship.

As discussed in the theoretical background, individuals in high PDI cultures are less sensitive towards ethical acts and more tolerant of inequality (Chan and Cheung 2012; House et al. 2004; Scholtens and Dam 2007). Accordingly, they may use the flexibility given by the standards to defend the rights of powerful parties, such as majority shareholders in their firms. As this value is shared by the vast majority in their society, managers believe that such 

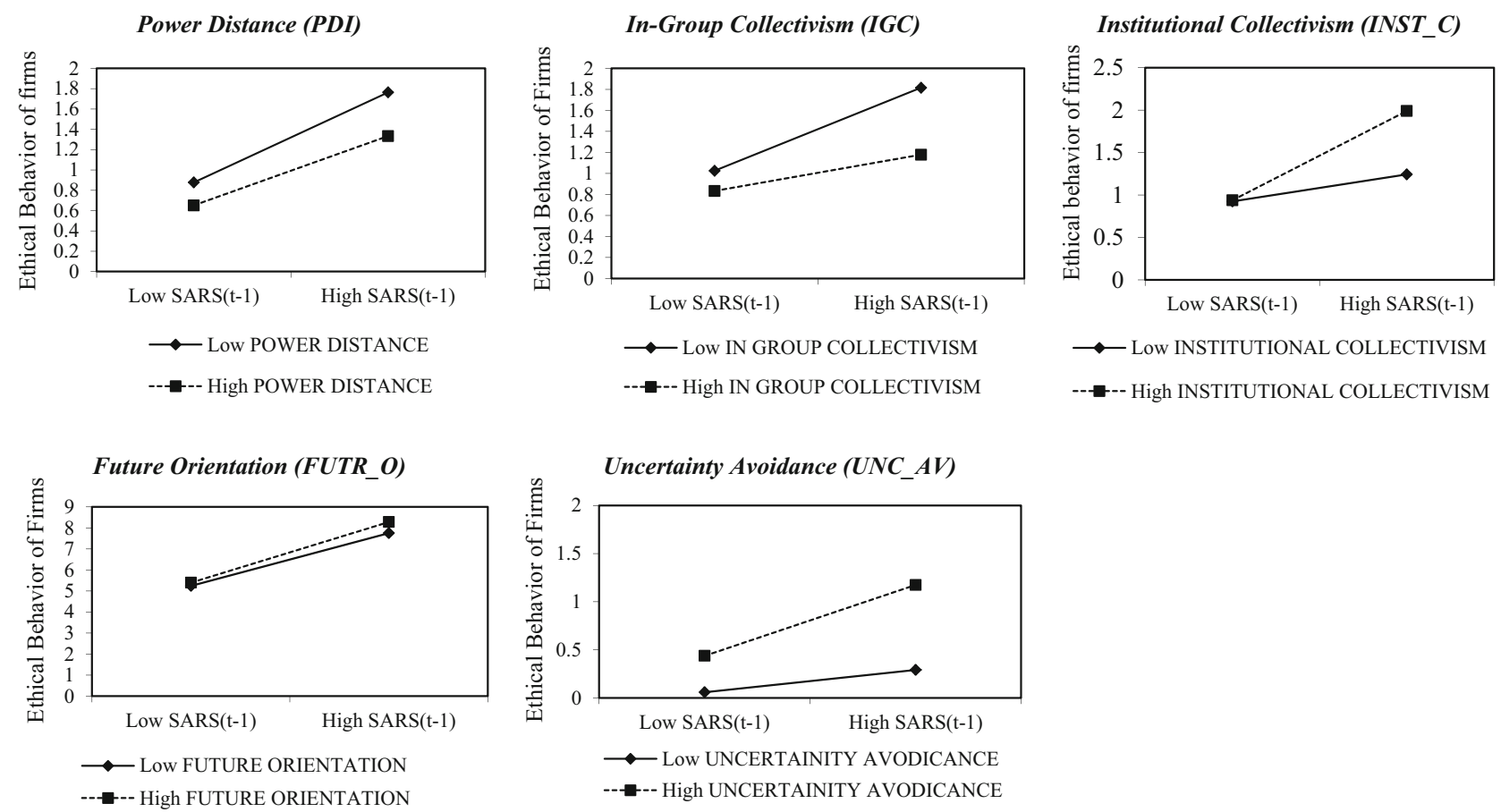

Fig. 1 The moderating role of culture on EBF and SARS relation

behaviour is both normal and expected. Therefore, at every opportunity, they are willing to interpret the grey areas in the standards to serve the interests of powerful parties. Accordingly, the impact of standards is weaker in terms of encouraging EBF in high PDI societies.

IGC has a very similar impact on SARS-EBF relationship. When IGC is high, people tend to protect the interests of their in-group at the expense of those of the out-groups (Franke and Nadler 2008). Therefore, when interpreting the auditing and reporting standards, their decisions are more likely to favour the interests of their in-groups rather than to support the rights of all. Hence, the impact of SARS tends to be weaker in those societies. Therefore, as societies characterized by high PDI and IGC, standards are unable to make the desired impact in terms of stimulating EBF.

The results of our sensitivity analysis, which is conducted with cultural clusters, are also in line with these findings as they indicate that the high score on IGC and medium score on PDI are among the common characteristic of societies where the positive association between SARS and EBF is weaker.

\section{Strengthening Moderating Impact of INST_C,} FUTR_O and UAI

Our results provided empirical evidence regarding the strengthening moderating impact of INST_C and FUTR_O, in line with our hypotheses. As previously explained, INST_C and FUTR_O have some commonalities. INST_C is defined as considering the interests of all related parties of an institution with a long-term focus; long-term focus and sustainability are also at the core of FUTR_O. In other words, managers are more willing to make sustainable and ethical decisions while interpreting the standards in high institutional collectivist and high future oriented societies.

Our findings about the moderating impact of IGC and INST_C are also important, as they show that these two dimensions of culture have inverse moderating impacts on SARS-EBF relationship. Although clearly defined as separate in the GLOBE project (House et al. 2004), previous researchers either used the term "collectivism" to refer to (a combination of) either types, or to refer to IGC alone, thus completely ignoring the existence of INST_C. Our research has contributed to the literature not only by providing empirical evidence that they are two distinct dimensions, but also showing that they may have differentsometimes inverse-impacts on social issues. Thus, we recommend researchers to take into account this finding, and incorporate IGC and INST_C separately in their future research.

Our results did not support our hypothesis regarding the impact of UAI. Although expected to have a weakening impact on the SARS-EBF relationship, UAI has statistically significant strengthening impact according to our results. Researchers generally hypothesize an inverse relationship between UAI and ethical behaviour due to 
Table 4 Regression results of EBF on IFRS and GLOBE cultural values

\begin{tabular}{|c|c|c|c|c|c|c|c|c|}
\hline Dependent variable $\mathrm{EBF}_{i t}$ & Model 1 & Model 2 & Model 3 & Model 4 & Model 5 & Model 6 & Model 7 & Model 8 \\
\hline Constant & 0.184 & $-3.774 * * *$ & $-3.421 * * *$ & $-4.351 * * *$ & $2.402 * * *$ & $-3.953 * * *$ & -1.402 & $-3.583 * * *$ \\
\hline \multicolumn{9}{|l|}{ Test variables } \\
\hline IFRS $_{i t}$ & $0.056^{* *}$ & $0.003^{*}$ & $0.048 * *$ & $0.113 * *$ & $0.101 * *$ & $0.002 *$ & $0.033 * *$ & $0.078 * *$ \\
\hline $\mathrm{PDI}_{i t}$ & $-0.433 * * *$ & & & & & & & \\
\hline FUTR_O $_{i t}$ & & $0.700 * * *$ & & & & & & \\
\hline HUM_O ${ }_{i t}$ & & & $0.201 * * *$ & & & & & \\
\hline PERF_O $_{i t}$ & & & & $0.677 * * *$ & & & & \\
\hline $\mathrm{IGC}_{i t}$ & & & & & $-0.570 * * *$ & & & \\
\hline INST_C $_{i t}$ & & & & & & $0.541 * * *$ & & \\
\hline $\operatorname{ASSERT}_{i t}$ & & & & & & & $-0.273 * * *$ & \\
\hline $\mathrm{UAI}_{i t}$ & & & & & & & & $0.789 * * *$ \\
\hline \multicolumn{9}{|l|}{ Control variables } \\
\hline COMPETITION $_{i t}$ & $0.902 * * *$ & $0.724 * * *$ & $0.958 * * *$ & $0.762 * * *$ & $0.917 * * *$ & $0.814 * * *$ & $0.966 * * *$ & $0.593 * * *$ \\
\hline $\mathrm{COMMON}_{i}$ & -0.146 & -0.136 & -0.095 & -0.131 & -0.059 & -0.189 & -0.115 & -0.105 \\
\hline $\operatorname{lnGDP}$ per capita ${ }_{i t}$ & $0.282 * * *$ & $0.259 * * *$ & $0.309 * * *$ & $0.286 * * *$ & $0.119 * * *$ & $0.272 * * *$ & $0.298 * * *$ & $0.245^{* * *}$ \\
\hline Cluster dummies & Yes & Yes & Yes & Yes & Yes & Yes & Yes & Yes \\
\hline Prob $>F$ & 0.000 & 0.000 & 0.000 & 0.000 & 0.000 & 0.000 & 0.000 & 0.000 \\
\hline$R^{2}$ & $0.799 * * *$ & $0.830 * * *$ & $0.785^{* * *}$ & $0.814 * * *$ & $0.856^{* * *}$ & $0.810 * * *$ & $0.786^{* * *}$ & $0.876^{* * *}$ \\
\hline
\end{tabular}

$E B F_{i t}$ the perceived ethical behaviours of firms, $S A R S_{i t-1}$ the perceived strength of accounting and auditing standards of previous year, $P D I_{i t}$ power distance, FUTR_O $O_{i t}$ future orientation, $H U M_{-} O_{i t}$ human orientation, $P E R F_{-} O_{i t}$ performance orientation, $I G C_{i t}$ in-group collectivism, $I N S T_{-} C_{i t}$ institutional collectivism, ASSERT $T_{i t}$ assertiveness, $U A I_{i t}$ uncertainty avoidance, COMPETITION $N_{i t}$ market competition, COMMON country legal origin, $\ln G D P$ per capita ${ }_{i t}$ natural logarithm of Gross domestic product per capita in current US dollars, Cluster dummies the dummy variables to control the effect of cultural clusters defined in the GLOBE study

$*$, **, *** $p<0.10,<0.05$ and $<0.01$ (one-sided tests), respectively. $n=324$ society-year observations between the years 2007 and 2012

deadening impact of UAI on ethical sensitivity (Chan and Cheung 2012; Vitell et al. 1993; Weaver 2001). However, positive or insignificant results have also been reported (Alas 2006; Scholtens and Dam 2007). A possible explanation for this finding is that in high UAI societies, managers may be less willing to take risks, especially in regard to accounting issues (Cieslewicz 2013). This may lead to over caution when interpreting the standards or use flexibility allowed by the standards, as they attempt to satisfy all relevant stakeholders' interests in the long term. Therefore, the standards may be more effective in stimulating EBF in high UAI societies. However, the strengthening moderating impact of UAI should be explored in future research, considering the conflicting results in the literature, our contradictory expectations, and the sensitivity check results we found using Hofstede's framework.

\section{Implications for Managers and Policy Makers}

Our results show that cultural values have the potential to accentuate or decrease the impact of SARS on EBF. This finding is important both for policy makers and managers. Policy makers should be aware of the clear need for all countries to find their own path to the achievement of the expected benefit from the implementation of auditing and reporting standards. This leads to a discussion over whether adaption or adoption of the standards will be more beneficial for a particular country. According to the International Accounting Standards Board, full adoption with reporting and auditing standards are required in order to derive the expected benefit from their application. However, many jurisdictions face cultural difficulties, both before and after the period of transition to auditing and reporting standards. In order to minimize the effect of such difficulties and mitigate the possible problems which may reduce the impact of SARS on EBF, policy makers should evaluate the national culture, and adapt the new regulations accordingly. Thus, enforcement and oversight mechanisms will be strengthened, and professional training programs will be adjusted to increase the awareness of the need for the transition to new standards and their expected benefits for all society. During this process, particularly, the importance of having a code of business ethics should be addressed by regulators.

Our findings also highlight the need for managers to be aware of the impact of cultural values in their practices. In order to increase their awareness on this issue, training 
Table 5 Two way moderating regression results of EBF on IFRS and GLOBE cultural values

\begin{tabular}{|c|c|c|c|c|c|c|c|c|}
\hline Dependent variable $\mathrm{EBF}_{i t}$ & Model 1 & Model 2 & Model 3 & Model 4 & Model 5 & Model 6 & Model 7 & Model 8 \\
\hline Constant & $-1.335 * *$ & $-2.509 * * *$ & $-2.642 * *$ & -3.465 & $-1.841 * * *$ & $-2.693 * * *$ & $-2.266^{* *}$ & $-2.643 * * *$ \\
\hline \multicolumn{9}{|l|}{ Test variables } \\
\hline $\mathrm{IFRS}_{i t}$ & $2.523 * * *$ & $2.359 * * *$ & $1.254 * *$ & $1.740 * * *$ & $1.700 * * *$ & $2.164 * * *$ & $1.903 * *$ & $1.748 * * *$ \\
\hline $\mathrm{PDI}_{i t}$ & -0.144 & & & & & & & \\
\hline FUTR_O $i t$ & & $0.367 * *$ & & & & & & \\
\hline HUM_O$_{i t}$ & & & 0.040 & & & & & \\
\hline PERF_O $_{i t}$ & & & & $0.414 * * *$ & & & & \\
\hline $\mathrm{IGC}_{i t}$ & & & & & $0.474 * * *$ & & & \\
\hline INST_C $C_{i t}$ & & & & & & $0.253 * * *$ & & \\
\hline $\operatorname{ASSERT}_{i t}$ & & & & & & & -0.044 & \\
\hline $\mathrm{UAI}_{i t}$ & & & & & & & & $0.524 * * *$ \\
\hline PDI $*$ IFRS $_{i t}$ & $-0.499 * * *$ & & & & & & & \\
\hline FUTR_O $*$ IFRS $_{i t}$ & & $0.619 * * *$ & & & & & & \\
\hline HUM_O $*$ IFRS $_{i t}$ & & & $0.293 * *$ & & & & & \\
\hline PERF_O $*$ IFRS $_{i t}$ & & & & $0.449 * * *$ & & & & \\
\hline $\mathrm{IGC}^{*} \mathrm{IFRS}_{i t}$ & & & & & $-0.155 * *$ & & & \\
\hline INST_C $^{*}$ IFRS $_{i t}$ & & & & & & $0.506^{* * *}$ & & \\
\hline ASSERT $^{*}$ IFRS $_{i t}$ & & & & & & & $-0.470 * * *$ & \\
\hline UAI $*$ IFRS $_{i t}$ & & & & & & & & $0.408 * * *$ \\
\hline \multicolumn{9}{|l|}{ Control variables } \\
\hline COMPETITION $_{i t}$ & $0.874 * * *$ & $0.687 * * *$ & $0.951 * * *$ & $0.766^{* * *}$ & $0.893 * * *$ & $0.791 * * *$ & $0.972 * * *$ & $0.604 * * *$ \\
\hline $\mathrm{COMMON}_{i}$ & -0.186 & -0.192 & -0.100 & -0.144 & -0.031 & -0.202 & -0.097 & 0.152 \\
\hline lnGDP per capita $i t$ & $0.293 * * *$ & $0.277 * * *$ & $0.302 * * *$ & $0.308 * * *$ & $0.136 * * *$ & $0.281 * * *$ & $0.288 * * *$ & $0.254 * * *$ \\
\hline Cluster dummies & Yes & Yes & Yes & Yes & Yes & Yes & Yes & Yes \\
\hline Prob $>F$ & 0.000 & 0.000 & 0.000 & 0.000 & 0.000 & 0.000 & 0.000 & 0.000 \\
\hline$R^{2}$ & $0.806^{* * *}$ & $0.845^{* * *}$ & $0.788 * * *$ & $0.819 * * *$ & $0.858 * * *$ & $0.819 * * *$ & $0.835 * * *$ & $0.887 * * *$ \\
\hline
\end{tabular}

$\overline{E B F_{i t} \text { the perceived ethical behaviours of firms, } S A R S_{i t-1} \text { the perceived strength of accounting and auditing standards of previous year, } P D I_{i t}}$ power distance, FUTR_O $O_{i t}$ future orientation, HUM_O $O_{i t}$ human orientation, $P E R F \_O_{i t}$ performance orientation, $I G C_{i t}$ in-group collectivism, $I N S T_{-} C_{i t}$ institutional collectivism, ASSERT $T_{i t}$ assertiveness, UNC_A $V_{i t}$ uncertainty avoidance, COMPETITION ${ }_{i t}$ market competition, $C_{C O M M O N}$ country legal origin, InGDP per capita $_{i t}$ natural logarithm of Gross domestic product per capita in current US dollars, Cluster dummies the dummy variables to control the effect of cultural clusters defined in the GLOBE study

*, **, *** $p<0.10,<0.05$ and $<0.01$ (one-sided tests), respectively. $n=324$ society-year observations between the years 2007 and 2012

programs should emphasize the importance of gaining an understanding of the cultural characteristics of societies with which they have business relationships. Such programs should focus on cultural values and their moderating impacts on associations between principle-based standards and EBF, enabling managers to develop customized strategies designed to enhance ethical behaviours in their firms. Moreover, our findings can be utilized in the management of subsidiaries in countries with different cultural values from the parent company. Care should be taken when adapting rules and policies for a subsidiary, taking into account the local cultural environment. For instance, in the case of countries which score high in PDI and IGC, and low in INST_C, UAI and FUTR_O, managers may need to set additional control mechanisms and strict rules at the firm level to ensure ethical behaviours. In contrast, where the local cultural environment of subsidiaries strengthens the impact of principle-based standards on ethical behaviours, parent companies can be more flexible towards their local managers, and allow them greater freedom to select ethical approaches. Therefore, by indicating the moderating impact of culture, our results provide useful insights to international managers to support ethical behaviours among their different subsidiaries through customized standards and policies.

\section{Limitations and Future Research}

Measuring the complex issue of EBF with a single item rather than a more comprehensive measurement can be considered as a limitation of the study. However, due to the large number of societies used to provide a cross-cultural comparison, it was essential to use the WCI as the most reliable data source, which included cross national data. 


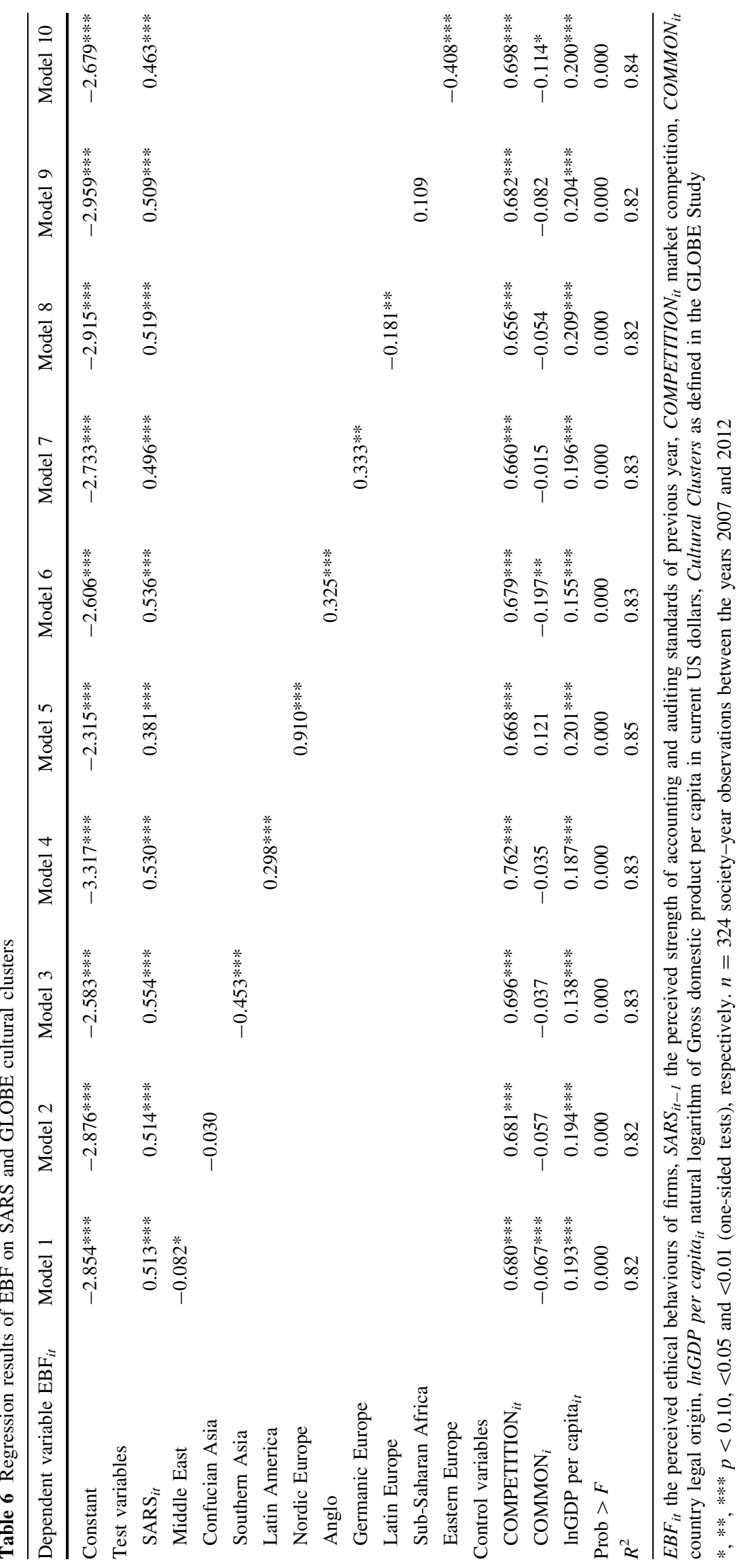




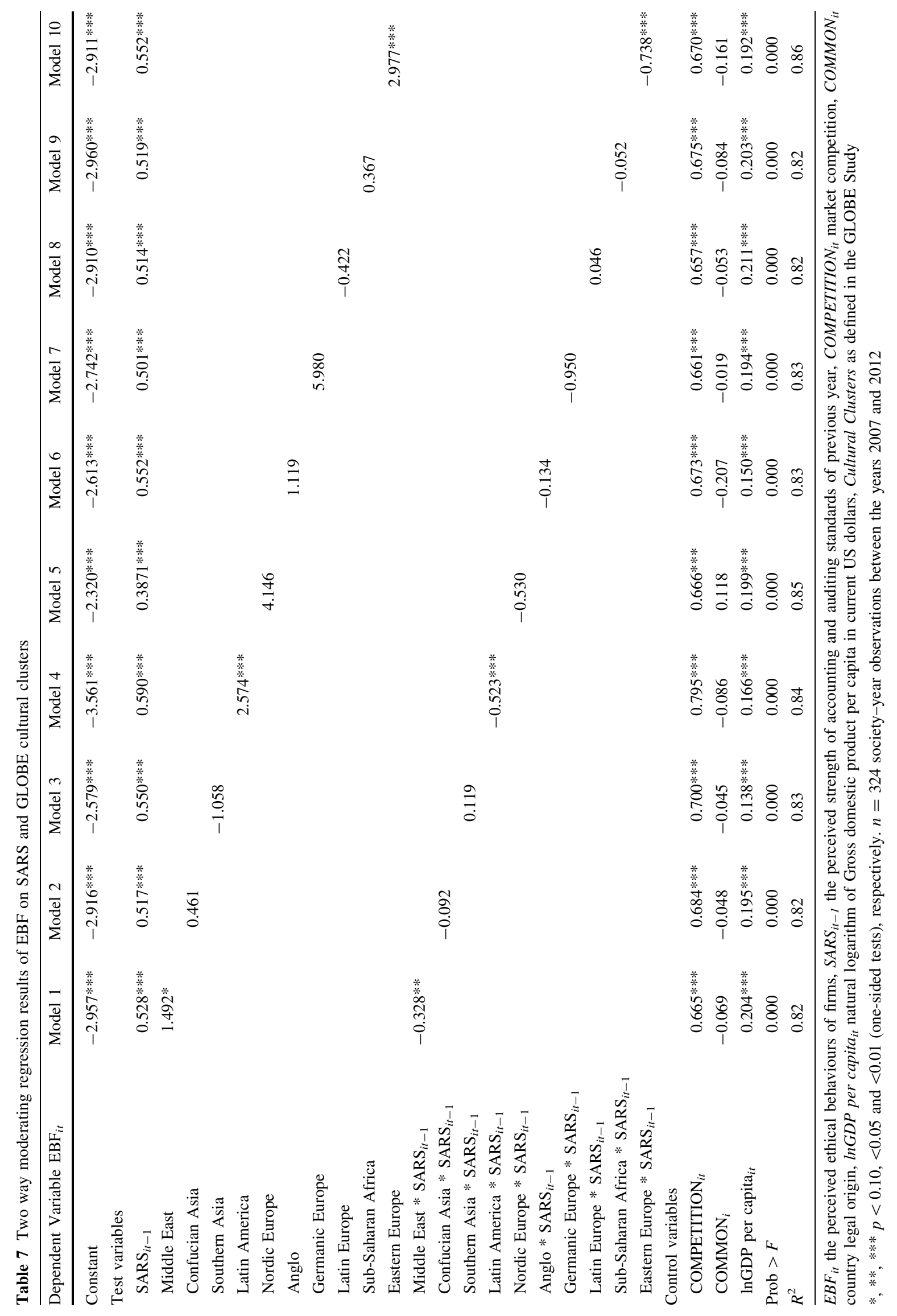


Table 8 Regression results of EBF on Hofstede cultural values and two way moderating impact

\begin{tabular}{|c|c|c|c|c|c|c|c|c|}
\hline \multirow[t]{2}{*}{ Dependent variable $\mathrm{EBF}_{i t}$} & \multicolumn{4}{|c|}{ Panel A: SARS and Culture as predictors } & \multicolumn{4}{|c|}{ Panel B: The Moderating Effect } \\
\hline & Model 1 & Model 2 & Model 3 & Model 4 & Model 5 & Model 6 & Model 7 & Model 8 \\
\hline Constant & $-1.356 * * *$ & -2.741 & $-2.364 * * *$ & $-2.464 * * *$ & $-3.470 * * *$ & $-0.633 * * *$ & $-3.717 * * *$ & $-3.430 * * *$ \\
\hline \multicolumn{9}{|l|}{ Test variables } \\
\hline SARS $_{i t}$ & $0.270 * * *$ & $0.364 * * *$ & $0.341 * * *$ & $0.371 * * *$ & $0.656 * * *$ & $0.177 * *$ & $0.593 * * *$ & $0.573 * * *$ \\
\hline $\mathrm{PDI}_{i t}$ & $-0.010 * * *$ & & & & $0.022 * *$ & & & \\
\hline $\mathrm{IDV}_{i t}$ & & $0.002 *$ & & & & $-0.062 * * *$ & & \\
\hline $\mathrm{MAS}_{i t}$ & & & $-0.008 * * *$ & & & & $0.018 *$ & \\
\hline $\mathrm{UAI}_{i t}$ & & & & $-0.003 * * *$ & & & & $0.012 * * *$ \\
\hline PDI $* \mathrm{SARS}_{i t-1}$ & & & & & $-0.006 * * *$ & & & \\
\hline $\mathrm{IDV}^{*} \mathrm{SARS}_{i t-1}$ & & & & & & $0.011 * * *$ & & \\
\hline MAS $*$ SARS $_{i t-1}$ & & & & & & & $-0.005^{* *}$ & \\
\hline UAI $*$ SARS $_{i t-1}$ & & & & & & & & $-0.003^{*}$ \\
\hline \multicolumn{9}{|l|}{ Control variables } \\
\hline COMPETITION $_{i t}$ & $0.872 * * *$ & $0.820 * * *$ & $0.772 * * *$ & $0.770 * * *$ & $0.866 * * *$ & $0.864 * * *$ & $0.789 * * *$ & $0.785 * * *$ \\
\hline $\mathrm{COMMON}_{i}$ & -0.078 & -0.016 & 0.101 & -0.077 & -0.066 & 0.0003 & 0.110 & -0.098 \\
\hline lnGDP per capita $i t$ & $0.133 * * *$ & $0.179 * * *$ & $0.226 * * *$ & $0.208 * * *$ & $0.135 * * *$ & $0.229 * * *$ & $0.218^{* * *}$ & $0.190 * * *$ \\
\hline Prob $>F$ & 0.000 & 0.000 & 0.000 & 0.000 & 0.000 & 0.000 & 0.000 & 0.000 \\
\hline$R^{2}$ & 0.78 & 0.76 & 0.78 & 0.76 & 0.79 & 0.78 & 0.78 & 0.76 \\
\hline
\end{tabular}

$E B F_{i t}$ the perceived ethical behaviours of firms, $S A R S_{i t-1}$ the perceived strength of accounting and auditing standards of previous year, $P D I_{i t}$ power distance, $I V D_{i t}$ individualism versus collectivism, $M A S_{i t}$ masculinity versus femininity, $U A I_{i t}$ uncertainty avoidance, $C O M P E T I T I O N_{i t}$ market competition, $C O M M O N_{i t}$ country legal origin, InGDP per capita ${ }_{i t}$ natural logarithm of Gross domestic product per capita in current US dollars

*, **, *** $p<0.10,<0.05$ and $<0.01$ (one-sided tests), respectively. $n=426$ country-year observations between the years 2006 and 2012

Therefore, EBF measurement by WCI was considered the most appropriate alternative for the current study.

Also, as indicated in the "Introduction" section, our independent and dependent variables depended on perceptions, not the absolute indicators. Although, perceptions could be subjective and misleading, they reflect the opinions of executives who have deep knowledge of business environment in their countries. Still, our results can be tested with different indicators in a future study.

Another limitation of the study is the relatively narrow focus on the impact of factors that may affect ethical behaviours, limited to SARS and culture. However, ethical behaviour is a complex issue which is affected by many other factors. Therefore, in order to increase our understanding of the mechanisms which accentuate or decrease ethical behaviour, future research may focus on more complex models, incorporating organizational factors such as organizational culture and strength of human resources management systems, in addition to SARS and national culture.

Moreover, in this study, we hypothesized that performance orientation, human orientation and assertiveness had moderating impacts on the SARS-EBF relationship. However, our data provided no empirical support for these hypotheses and it would therefore be enlightening if future research explores the moderating impacts of these factors in a micro-level sample setting.

Finally, testing our results across sectors could be very interesting and useful in order to identify sector-based variations. Unfortunately, our data set did not include sector-based data either for SARS or EBF. Therefore, in a future study, sector-based results can be compared with a different data set.

\section{Conclusion}

Our findings contribute to the literature by addressing the moderating role of national culture in the relationship between SARS and EBF. Overall, we find evidence supporting the idea that national culture affects the relationship between SARS and EBF. The main implication of our study is that encouraging ethical behaviour is a complex issue, and that in themselves, universal standards to enhance EBF are inadequate, because any regulation that does not consider cultural impact is likely to fail to have the required effect. Thus, it is important for policy makers to put in place the necessary enforcement mechanisms for the effective implementation of auditing and reporting standards. 
Open Access This article is distributed under the terms of the Creative Commons Attribution License which permits any use, distribution, and reproduction in any medium, provided the original author(s) and the source are credited.

\section{Appendix 1}

GLOBE Cultural Clusters with Associated Countries and Their Cultural Values

\begin{tabular}{|c|c|c|c|}
\hline \multirow{2}{*}{$\begin{array}{l}\text { Clusters } \\
\text { Nordic } \\
\text { Eurone }\end{array}$} & \multirow{2}{*}{$\frac{\text { Countries }}{\text { Denmark }}$} & \multicolumn{2}{|c|}{ Cultural values } \\
\hline & & \multirow[t]{5}{*}{ High } & Future orientation \\
\hline & \multirow{9}{*}{$\begin{array}{l}\text { Finland } \\
\text { Iceland } \\
\text { Norway } \\
\text { Sweden }\end{array}$} & & Gender \\
\hline & & & egalitarianism \\
\hline & & & Institutional \\
\hline & & & $\begin{array}{c}\text { Uncertainty } \\
\text { avoidance }\end{array}$ \\
\hline & & Medium & Humane orientation \\
\hline & & & $\begin{array}{r}\text { Performance } \\
\text { orientation }\end{array}$ \\
\hline & & Low & Assertiveness \\
\hline & & & $\begin{array}{l}\text { In-group } \\
\text { collectivism }\end{array}$ \\
\hline & & & Power distance \\
\hline \multirow{10}{*}{$\begin{array}{c}\text { Germanic } \\
\text { Europe }\end{array}$} & \multirow{10}{*}{$\begin{array}{l}\text { Austria } \\
\text { East Germany } \\
\text { West Germany } \\
\text { The Netherlands } \\
\text { Switzerland }\end{array}$} & High & Assertiveness \\
\hline & & & Future orientation \\
\hline & & & Performance \\
\hline & & & orientation \\
\hline & & & $\begin{array}{r}\text { Uncertainty } \\
\text { avoidance }\end{array}$ \\
\hline & & Medium & $\begin{array}{l}\text { Gender } \\
\text { egalitarianism }\end{array}$ \\
\hline & & & Power distance \\
\hline & & Low & Human orientation \\
\hline & & & $\begin{array}{l}\text { Institutional } \\
\text { collectivism }\end{array}$ \\
\hline & & & $\begin{array}{l}\text { In-group } \\
\text { collectivism }\end{array}$ \\
\hline \multirow[t]{11}{*}{ Anglo Cluster } & \multirow{2}{*}{$\begin{array}{l}\text { Australia } \\
\text { Canada (English } \\
\text { speaking) }\end{array}$} & High & $\begin{array}{c}\text { Performance } \\
\text { orientation }\end{array}$ \\
\hline & & Medium & Assertiveness \\
\hline & \multirow{9}{*}{$\begin{array}{l}\text { England } \\
\text { Ireland } \\
\text { New Zealand } \\
\text { South Africa (White } \\
\text { sample) } \\
\text { The USA }\end{array}$} & & Future orientation \\
\hline & & & Gender \\
\hline & & & egalitarianism \\
\hline & & & Humane orientation \\
\hline & & & Institutional \\
\hline & & & collectivism \\
\hline & & & Power distance \\
\hline & & & $\begin{array}{r}\text { Uncertainty } \\
\text { avoidance }\end{array}$ \\
\hline & & Low & $\begin{array}{l}\text { In-group } \\
\text { collectivism }\end{array}$ \\
\hline
\end{tabular}

\begin{tabular}{|c|c|c|c|}
\hline \multirow{3}{*}{$\begin{array}{l}\text { Clusters } \\
\text { Latin } \\
\text { European }\end{array}$} & \multirow{2}{*}{$\begin{array}{l}\text { Countries } \\
\text { France }\end{array}$} & \multicolumn{2}{|c|}{ Cultural values } \\
\hline & & High & - \\
\hline & Israel & Medium & Assertiveness \\
\hline & Italy & & Future orientation \\
\hline & Portugal & & Gender \\
\hline & Spain & & egalitarianism \\
\hline & $\begin{array}{l}\text { Switzerland (French } \\
\text { speaking) }\end{array}$ & & $\begin{array}{l}\text { In-group } \\
\text { collectivism }\end{array}$ \\
\hline & & & Power distance \\
\hline & & & $\begin{array}{r}\text { Uncertainty } \\
\text { avoidance }\end{array}$ \\
\hline & & & $\begin{array}{r}\text { Performance } \\
\text { orientation }\end{array}$ \\
\hline & & Low & Humane orientation \\
\hline & & & $\begin{array}{l}\text { Institutional } \\
\text { collectivism }\end{array}$ \\
\hline \multirow{11}{*}{$\begin{array}{l}\text { Latin } \\
\text { America }\end{array}$} & \multirow{11}{*}{$\begin{array}{l}\text { Ecuador } \\
\text { El Salvador } \\
\text { Columbia } \\
\text { Bolivia } \\
\text { Brazil } \\
\text { Guatemala } \\
\text { Argentina } \\
\text { Costa Rica } \\
\text { Venezuela } \\
\text { Mexico }\end{array}$} & High & In-group \\
\hline & & & collectivism \\
\hline & & Medium & Assertiveness \\
\hline & & & Human orientation \\
\hline & & & Gender \\
\hline & & & egantarianism \\
\hline & & & Power distance \\
\hline & & Low & Future orientation \\
\hline & & & $\begin{array}{l}\text { Institutional } \\
\text { collectivism }\end{array}$ \\
\hline & & & $\begin{array}{r}\text { Performance } \\
\text { orientation }\end{array}$ \\
\hline & & & $\begin{array}{r}\text { Uncertainty } \\
\text { avoidance }\end{array}$ \\
\hline \multirow{11}{*}{$\begin{array}{l}\text { Eastern } \\
\text { Europe }\end{array}$} & \multirow{11}{*}{$\begin{array}{l}\text { Albania } \\
\text { Georgia } \\
\text { Greece } \\
\text { Hungary } \\
\text { Kazakhstan } \\
\text { Poland } \\
\text { Russia } \\
\text { Slovenia }\end{array}$} & High & Assertiveness \\
\hline & & & Gender \\
\hline & & & egalitarianism \\
\hline & & & In-group \\
\hline & & Medium & Inctitutiongl \\
\hline & & Miedium & collectivism \\
\hline & & & Humane orientation \\
\hline & & & Power distance \\
\hline & & Low & Future orientation \\
\hline & & & $\begin{array}{r}\text { Performance } \\
\text { orientation }\end{array}$ \\
\hline & & & $\begin{array}{r}\text { Uncertainty } \\
\text { avoidance }\end{array}$ \\
\hline \multirow{7}{*}{$\begin{array}{l}\text { The Middle } \\
\text { East }\end{array}$} & \multirow{3}{*}{$\begin{array}{l}\text { Turkey } \\
\text { Kuwait } \\
\text { Eoynt }\end{array}$} & High & In-group \\
\hline & & & collectivism \\
\hline & & Medium & Assertiveness \\
\hline & Morocco & & Humane orientation \\
\hline & Qatar & & $\begin{array}{l}\text { Institutional } \\
\text { collectivism }\end{array}$ \\
\hline & & & $\begin{array}{r}\text { Performance } \\
\text { orientation }\end{array}$ \\
\hline & & & Power distance \\
\hline
\end{tabular}




\begin{tabular}{|c|c|c|c|}
\hline Clusters & Countries & Cultural & values \\
\hline \multirow{3}{*}{ Confucian Asia } & \multirow{4}{*}{$\begin{array}{l}\text { China } \\
\text { Hong Kong } \\
\text { Japan } \\
\text { Singapore }\end{array}$} & Low & $\begin{array}{l}\text { Future orientation } \\
\text { Gender } \\
\text { egalitarianism } \\
\text { Uncertainty } \\
\text { avoidance }\end{array}$ \\
\hline & & High & $\begin{array}{l}\text { In-group } \\
\text { collectivism } \\
\text { Institutional } \\
\text { collectivism } \\
\text { Performance } \\
\text { orientation }\end{array}$ \\
\hline & & Medium & $\begin{array}{l}\text { Assertiveness } \\
\text { Future orientation } \\
\text { Gender } \\
\text { egalitarianism } \\
\text { Humane } \\
\text { orientation } \\
\text { Power distance } \\
\text { Uncertainty } \\
\text { avoidance }\end{array}$ \\
\hline \multirow{4}{*}{ Southern Asia } & & Low & - \\
\hline & \multirow{3}{*}{$\begin{array}{l}\text { India } \\
\text { Indonesia } \\
\text { Iran } \\
\text { Malaysia } \\
\text { Philippines } \\
\text { Thailand }\end{array}$} & High & $\begin{array}{l}\text { Humane } \\
\text { orientation } \\
\text { In-group } \\
\text { collectivism }\end{array}$ \\
\hline & & Medium & $\begin{array}{l}\text { Assertiveness } \\
\text { Future orientation } \\
\text { Gender } \\
\text { egalitarianism } \\
\text { Institutional } \\
\text { collectivism } \\
\text { Performance } \\
\text { orientation } \\
\text { Power distance } \\
\text { Uncertainty } \\
\text { avoidance }\end{array}$ \\
\hline & & Low & - \\
\hline \multirow[t]{9}{*}{$\begin{array}{l}\text { Sub-Saharan } \\
\text { Africa }\end{array}$} & $\begin{array}{l}\text { Namibia } \\
\text { Nigeria }\end{array}$ & High & $\begin{array}{l}\text { Humane } \\
\text { orientation }\end{array}$ \\
\hline & $\begin{array}{l}\text { South Africa (Black } \\
\text { sample) }\end{array}$ & Medium & $\begin{array}{l}\text { Assertiveness } \\
\text { Future orientation }\end{array}$ \\
\hline & $\begin{array}{l}\text { Zambia } \\
\text { Zimbabwe }\end{array}$ & & $\begin{array}{l}\text { Gender } \\
\text { egalitarianism }\end{array}$ \\
\hline & & & $\begin{array}{l}\text { In-group } \\
\text { collectivism }\end{array}$ \\
\hline & & & $\begin{array}{l}\text { Institutional } \\
\text { collectivism }\end{array}$ \\
\hline & & & $\begin{array}{r}\text { Performance } \\
\text { orientation }\end{array}$ \\
\hline & & & Power distance \\
\hline & & & $\begin{array}{l}\text { Uncertainty } \\
\text { avoidance }\end{array}$ \\
\hline & & Low & - \\
\hline
\end{tabular}

Note This table is derived from the results presented in the GLOBE Study of 62 Societies (House et al. 2004)

\section{References}

Alas, R. (2006). Ethics in countries with different cultural dimensions. Journal of Business Ethics, 69, 237-247.

Alderson, S., \& Kakabadse, A. (1994). Business ethics and Irish management: A cross-cultural study. European Journal of Management, 4(12), 432-441.

American Psychological Association's (APA) ethical principles of psychologists and code of conduct. Retrieved June 19, 2013, from http://www.apa.org/ethics/code/index.aspx.

Apple business conduct. Retrieved June 19, 2013, from http://files. shareholder.com/downloads/AAPL/1635337056x0x443008/ 5f38b1e6-2f9c-4518-b691-13a29ac90501/business_conduct_pol icy.pdf.

Ball, R., Robin, A., \& Wu, J. S. (2003). Incentives versus standards: Properties of accounting income in four East Asian countries. Journal of Accounting and Economics, 36, 235-270.

Bartels, R. (1967). A model for ethics in marketing. Journal of Marketing, 31, 20-26.

Barth, M. E., Landsman, W. R., \& Lang, M. H. (2008). International accounting standards and accounting quality. Journal of Accounting Research, 46(3), 467-498.

Becker, H., \& Fritzsche, D. J. (1987). Business ethics: A crosscultural comparison of managers' attitudes. Journal of Business Ethics, 6, 289-295.

Blodgett, J. G., Lu, L. C., Rose, G. M., \& Vitell, S. J. (2001). Ethical sensitivity to stakeholders' interests: A cross-cultural comparison. Journal of Academy of Marketing Science, 29(2), 190-202.

Bodley, J. H. (2005). Cultural anthropology: Tribes, states and the global system. Boston: McGraw Hill.

Boolaky, P., \& O'Leary, C. (2011). Determining the strength of auditing standards and reporting. Corporate Ownership and Control, 8(4), 69-80.

Boolaky, P., \& O'Leary, C. (2012). Positive influences of governance, legal, educational and market factors on audit environments. Corporate Board: Role, Duties and Composition, 8(1), 69-80.

Carcello, J. V. (2009). Governance and the common good. Journal of Business Ethics, 89(1), 11-18.

Chan, A. W. H., \& Cheung, H. Y. (2012). Cultural dimensions, ethical sensitivity and corporate governance. Journal of Business Ethics, $110,45-59$.

Chen, H., Tang, Q., Jiang, Y., \& Lin, Z. (2010). The role of international financial reporting standards in accounting quality: Evidence from the European Union. Journal of International Financial Management and Accounting, 21(3), 220-278.

Chhokar, J. S., Brodbeck, F. C., \& House, R. J. (Eds.). (2012). Culture and leadership across the world: The GLOBE book of in-depth studies of 25 societies. London: Routledge.

Cieslewicz, J. K. Relationships between national economic culture, institutions, and accounting: Implications for IFRS. In Critical perspectives on accounting. ISSN 1045-2354. Accessed April 29, 2013, from doi:10.1016/j.cpa.2013.03.006.

Coca Cola code of business conduct. Retrieved May 20, 2013, from http://assets.coca-colacompany.com/45/59/f85d53a84ec597f74c 754003450c/COBC_English.pdf.

Coffee, J. (2001). Do norms matter? A cross-country examination of private benefits of control. Mimeo, Columbia University Law School.

Daske, H., Hail, L., Leuz, C., \& Verdi, R. (2008). Mandatory IFRS reporting around the world: Early evidence on the economic consequences. Journal of Accounting Research, 46(5), 1085-1142.

Ding, Y., Jeanjean, T., \& Stolowy, H. (2005). Why do national GAAP differ from IAS? The role of culture. The International Journal of Accounting, 40(4), 325-350. 
Dolecheck, M. M., \& Dolecheck, C. C. (1987). Business ethics: A comparison of attitudes of managers in Hong Kong and the United States. The Hong Kong Manager, (Apr/May), 28-43.

Doupnik, T. S., \& Riccio, E. L. (2006). The influence of conservatism and secrecy on the interpretation of verbal probability expressions in the Anglo and Latin cultural areas. The International Journal of Accounting, 41(3), 237-261.

Doupnik, T. S., \& Richter, M. (2003). Interpretation of uncertainty expressions: A cross-national study. Accounting, Organizations and Society, 28(1), 15-35.

Doupnik, T. S., \& Richter, M. (2004). The impact of culture on the interpretation of "in context" verbal probability expressions. Journal of International Accounting Research, 3(1), 1-20.

Dubinsky, A. J., Jolson, M. A., Kotabe, M., \& Lim, C. U. (1991). A cross-national investigation of industrial sales people's ethical perceptions. Journal of International Business Studies, 22(4), 651-670.

Ekici, A., \& Onsel, S. (2013). How ethical behavior of firms is influenced by the legal and political environments: A Bayesian causal map analysis based on stages of development. Journal of Business Ethics, 115(2), 271-290.

European Business Ethics Forum. Retrieved May 20, 2013, from http://www.ebef.eu/Past\%20Conference\%20Reports.html.

Felo, A. J. (2011). Corporate governance and business ethics. In B. Alexander (Ed.), Corporate governance and business ethics (pp. 281-296). Dordrecht: Springer.

Franke, G. R., \& Nadler, S. S. (2008). Culture, economic development, and national ethical attitudes. Journal of Business Research, 61, 254-264.

Friedman, B. M. (2006). The moral consequences of economic growth. Society, 43(2), 15-22.

García-Osma, B. (2006). Earnings quality, auditor monitoring and corporate governance mechanisms. Unpublished Doctoral Dissertation, Lancaster University, UK.

Garrison, R. H., Noreen, E. W., \& Brewer, P. C. (2008). Managerial accounting (12th ed.). New York: McGraw-Hill.

Gelfand, M. J., Bhawuk, P. S. Nishii, L. H., \& Bechtold, D. J. (2004). Individualism and collectivism. In R. House, et al. (eds.) Culture, leadership and organizations: The GLOBE study of 62 societies (pp. 473-512). Newbury Park, CA: Sage Publications.

Gillan, S. L. (2006). Recent developments in corporate governance: An overview. Journal of Corporate Finance, 12(3), 381-402.

Global Ethics Forum. Retrieved May 20, 2013, from http://www. globethics.net/web/gef.

Hall, E. T. (1959). The silent language (Vol. 3). New York: Doubleday.

Hawkins, C. E. (1993). A comparative study of the management accounting practices of individual companies in the United States and Japan. Ann Arbor, MI: University of Microfilms International.

Hoffman, W. M., \& Rowe, M. (2007). The ethics officer as agent of the board: Leveraging ethical governance capability in the postEnron Corporation. Business and Society Review, 112(4), 553-572.

Hofstede, G. (1980). Culture's consequences: Comparing values, behaviors, institutions, and organizations across nations. Thousand Oaks, CA: Sage.

Hofstede, G. (2001). Culture's consequences: International differences in work-related values (2nd ed.). Thousand Oaks, CA: Sage Publications, Incorporated.

House, R. J., Hanges, P. J., Javidan, M., Dorfman, P. W., \& Gupta, V. (2004). Culture, leadership, and organizations. (The GLOBE study of 62 societies). Thousand Oaks, CA: Sage Publications, Incorporated.

Hsiao, C. (2007). Panel data analysis-Advantages and challenges. Test, 16(1), 1-22.
Hunt, S. D., \& Vitell, S. (1992). The general theory of marketing ethics: A retrospective and revision. In J. Quelch \& C. Smith (Eds.), Ethics in marketing. Chicago: Richard D. Irwin.

IAS-16 (International Accounting Standards 16, 2013). Property, plant and equipment. London: IFRS Foundation.

IAS-18 (International Accounting Standards 18, 2013). Revenue. London: IFRS Foundation.

IAS-37 (International Accounting Standards 37, 2013). Provisions, contingent liabilities and contingent assets. London: IFRS Foundation.

Ienciu, I. A. (2012). Corporate governance and ethical behavior: A national perspective. Romanian Economic Journal, 15(35), 49-68.

IFAC. (2012). Handbook of the code of ethics for professional accountants. Retrieved June 19, 2013, from http://www.ifac.org/ publications-resources/2012-handbook-code-ethics-professionalaccountants.

ISA 200 (International Standard on Auditing 200, 2009). Retrieved June 19, 2013, from http://www.ifac.org/sites/default/files/pub lications/files/A009\%202012\%20IAASB\%20Handbook\%20ISA \%20200.pdf.

Jeanjean, T., \& Stolowy, H. (2008). Do accounting standards matter? An exploratory analysis of earnings management before and after IFRS adoption. Journal of Accounting and Public Policy, 27(6), 480-494

Kaptein, M. (2004). Business codes of multinational firms: What do they say? Journal of Business Ethics, 50(1), 13-31.

Karaibrahimoglu, Y. (2010). The role of corporate governance on earnings management: Quarterly evidence from Turkey. Unpublished Doctoral Dissertation, Izmir University of Economics, Turkey.

Karnes, A., Sterner, J., Welker, R., \& Wu, F. (1989). A bicultural study of independent auditors' perceptions of unethical business practices. International Journal of Accounting, 24, 29-41.

La Porta, R., López de Silanes, F., Shleifer, A., \& Vishny, R. (1998). Law and finance. Journal of Political Economy, 106, 1113-1155. Retrieved February 6, 2013, from http://www.economics. harvard.edu/faculty/shleifer/paper.

La Porta, R., Lopez-de-Silanes, F., Shleifer, A., \& Vishny, R. (2000). Investor protection and corporate governance. Journal of Financial Economics, 58(1), 3-27.

Langlois, C. C., \& Schlegelmilch, B. B. (1990). Do corporate codes of ethics reflect national character? Evidence from Europe and the United States. International Journal of Business Studies, 21, 519-539.

Liu, C., Yao, L. J., Hu, N., \& Liu, L. (2011). The impact of IFRS on accounting quality in a regulated market: An empirical study of China. Journal of Accounting, Auditing and Finance, 26(4), 659-676.

Mehanna, R. A., \& Yazbeck, Y. (2009). Business innovation, ethics, and prosperity: The primacy of microeconomics. Journal of Business Strategies, 26(2), 1-17.

Mensah, Y. M. (2013). An analysis of the effect of culture and religion on perceived corruption in a global context. Journal of Business Ethics,. doi:10.1007/s10551-013-1696-0.

Paananen, M. (2008). The IFRS adoption's effect on accounting quality in Sweden. University of Hertfordshire, Working Paper. Retrieved June 6, 2013, from http://www.adoptifrs.org/uploads/ Sweden/The $\% 20$ IFRS $\% 20 \% 20$ Effect $\% 20$ on $\% 20$ Accounting $\% 20$ Quality\%20in\%20Sweden.pdf.

Paananen, M., \& Lin, H. (2009). The development of accounting quality of IAS and IFRS over time: The case of Germany. Journal of International Accounting Research, 8(1), 31-55.

Parboteeah, P., Bronson, J., \& Cullen, J. (2005). Does national culture affect willingness to justify ethically suspected behaviors? International Journal of Cross-Cultural Management, 5(2), $125-138$. 
Perera, H. (1994). Culture and international accounting: Some thoughts on research issues and prospects. Advances in International Accounting, 7, 267-285.

Podsakoff, P. M., MacKenzie, S. B., \& Podsakoff, N. P. (2012). Sources of method bias in social science research and recommendations on how to control it. Annual Review of Psychology, 63, 539-569.

Qu, W., Fong, M., \& Oliver, J. (2012). Does IFRS convergence improve quality of accounting information?: Evidence from the Chinese stock market. Corporate Ownership and Control, 9(4), 187-196.

Rezaee, Z., Smith, L. M., \& Szendi, J. Z. (2010). Convergence in accounting standards: Insights from academicians and practitioners. Advances in Accounting, 26(1), 142-154.

Scholtens, B., \& Dam, L. (2007). Cultural values and international differences in business ethics. Journal of Business Ethics, 75, 273-284.

Schultz, J. J., Johnson, D. A., Morris, D., \& Dyrnes, S. (1993). An investigation of the reporting of questionable acts in international setting. Journal of Accounting Research, 31, 75-103.

Schwartz, S. H. (1992). Universals in the content and structure of values: Theoretical advances and empirical tests in 20 countries. In M. Zanna (Ed.), Advances in experimental psychology (Vol. 25, pp. 1-65). New York: Academic Press.

Shi, X., \& Wang, J. (2011). Interpreting Hofstede model and GLOBE model: Which way to go for cross-cultural research? International Journal of Business and Management, 6(5), 93-99.

Shleifer, A. (2004). Does competition destroy ethical behavior? (No. w10269). National Bureau of Economic Research.

Simga-Mugan, C., Daly, B. A., Onkal, D., \& Kavut, L. (2005). The influence of nationality and gender on ethical sensitivity: An application of the issue-contingent model. Journal of Business Ethics, 57, 139-159.

Sims, R. R. (1992). The challenge of ethical behavior in organizations. Journal of Business Ethics, 11(7), 505-513.

Smith, A., \& Hume, E. C. (2005). Linking culture and ethics: A comparison of accountant's ethical belief systems in the individualism/collectivism contexts. Journal of Business Ethics, 62, 209-220.

Steers, R. M., Nardon, L., \& Sanchez Runde, C. J. (2013). Management across cultures: Developing global competencies (2nd ed.). New York: Cambridge University Press.

The conceptual framework for financial statements. (2010). London: IFRS Foundation.

Trompenaars, F. (1994). Riding the waves of culture. Chicago: Irwin Professional Publishing.

Tsakumis, G. T. (2007). The influence of culture on accountants' application of financial reporting rules. Abacus, 43(1), 27-48.

Tsui, J. (1996). Auditors' ethical reasoning: Some audit conflict and cross-cultural evidence. International Journal of Accounting, 62, 209-220.

Venaik S., \& Brewer, P. A. (2008). Contradictions in national culture: Hofstede vs GLOBE. In J. Cantwell \& T. Kiyak (Eds.), Proceedings of the 50th annual meeting of the academy of international business (pp. 274-274). Milan: 50th Annual Meeting of the Academy of International Business.

Vitell, S. J., Nwachukwu, S. L., \& Barnes, J. H. (1993). The effects of culture on ethical decision making: An application of Hofstede's typology. Journal of Business Ethics, 12, 753-760.

WCI. (2012). The global competitiveness report. Retrieved March 6, 2013, from http://www.weforum.org/issues/competitiveness-0/ gci2012-data-platform/.

Weaver, G. R. (2001). Ethics programs in global business: Culture's role in managing ethics. Journal of Business Ethics, 30(1), 3-15.

Webley, S. (1999). Values inherent in the interfaith declaration of international business ethics. In G. Enderle (ed.) International business ethics: Challenges and approaches in Carcello, J. V. (2009). Governance and the common good. Journal of Business Ethics, 89(1), 11-18.

World Bank. (2012). GDP per capita data set. http://data.worldbank. org/indicator/NY.GDP.PCAP.CD.

Zhang, X., Liang, X., \& Sun, H. (2013). Individualism-collectivism, private benefits of control, and earnings management: A crosscultural comparison. Journal of Business Ethics, 114, 655-664. 